\title{
Androgen-Induced Immunosuppression
}

\author{
Melanie R. Gubbels Bupp ${ }^{1}$ and Trine N. Jorgensen ${ }^{2 *}$ \\ ${ }^{1}$ Biology Department, Randolph Macon College, Ashland, VA, United States, ${ }^{2}$ Department of Inflammation and Immunity, \\ Lerner Research Institute, Cleveland Clinic Foundation, Cleveland, $\mathrm{OH}$, United States
}

OPEN ACCESS

Edited by: Virginia Rider,

Pittsburg State University, United States

Reviewed by:

Maureen A. Su,

University of North

Carolina at Chapel Hill,

United States

William Joseph Kovacs,

Penn State Milton S.

Hershey Medical Center,

United States

*Correspondence:

Trine N. Jorgensen

jorgent@ccf.org

Specialty section: This article was submitted to Cytokines and Soluble Mediators in Immunity,

a section of the journal

Frontiers in Immunology

Received: 01 March 2018

Accepted: 03 April 2018

Published: 17 April 2018

Citation:

Gubbels Bupp MR

and Jorgensen TN (2018)

Androgen-Induced

Immunosuppression.

Front. Immunol. 9:794. doi: 10.3389/fimmu.2018.00794
In addition to determining biological sex, sex hormones are known to influence health and disease via regulation of immune cell activities and modulation of target-organ susceptibility to immune-mediated damage. Systemic autoimmune disorders, such as systemic lupus erythematosus, rheumatoid arthritis, and multiple sclerosis are more prevalent in females, while cancer shows the opposite pattern. Sex hormones have been repeatedly suggested to play a part in these biases. In this review, we will discuss how androgens and the expression of functional androgen receptor affect immune cells and how this may dampen or alter immune response(s) and affect autoimmune disease incidences and progression.

Keywords: androgen, testosterone, systemic lupus erythematosus, rheumatoid arthritis, multiple sclerosis, cancer, autoimmunity, sex hormones

\section{INTRODUCTION}

Sex hormones exert their effects on many cellular targets, including cells of the immune system. Indeed, sex hormones directly influence immune cell function and development as well as the susceptibility of cells and tissues to damage from aberrant (autoimmune) processes. In this review, we will discuss how androgens and the androgen receptor (AR) affect immune cells and how this may dampen or alter immune response(s) to affect disease incidence and progression.

\section{ANDROGEN AND ARs}

\section{Androgens}

The four androgen hormones, dihydrotestosterone (DHT), testosterone, androstenedione, and dehydroepiandrosterone (DHEA), are all synthesized from cholesterol in the gonads and adrenal glands (1). DHT is more potent than testosterone, while androstenedione and DHEA exhibit only 10 and $5 \%$ of the potency of testosterone, respectively (1). However, testosterone is the most concentrated androgen in adult male serum, with DHT present at one-tenth the concentration of testosterone. Testosterone can be converted to androstenedione (and vice versa) and both can be aromatized to estrogens by aromatase (2). Aromatase is widely expressed and thus studies in which testosterone and androstenedione have been used for in vivo treatment can be difficult to interpret. DHEA binds several steroid hormone receptors, including AR and estrogen receptors $\alpha$ and $\beta$, albeit with lower affinity than their cognate ligands (3). Moreover, DHEA can be reversibly modified to form DHEA-S, which can be peripherally metabolized to testosterone (especially in premenopausal women) and estrogens (especially in postmenopausal women) (3), further complicating our understanding of DHEA-mediated effects. Of the four androgens, only DHT cannot be converted to estrogens and thus, studies utilizing DHT are most easily interpreted. 


\section{Androgen Receptors}

Beyond its required role in the development and expression of male phenotypes, the AR regulates immune function via modulating the transcription of a number of genes by DNAbinding-dependent and -independent mechanisms (4). Encoded on the $\mathrm{X}$ chromosome, the $\mathrm{AR}$ is a signal transduction protein and transcription factor required for the development and expression of male phenotypes (4). The AR is bound by heat shock proteins and chaperones in the cytoplasm until bound by its ligands (5-10). Signal transduction through the classical AR is a multi-step process dependent upon receptor dimerization, the binding of ligand, interaction with cofactors, and DNA binding. Upon binding ligand, heat-shock proteins and chaperones are exchanged for cofactors, and the receptor:ligand complex translocates into the nucleus to bind specific DNA regulatory sequences [androgen response elements (AREs)] and regulate transcription (4). Due to the differences in binding affinities and dissociation constants, AR:DHT complexes remains bound to AREs longer than AR:testosterone complexes, further adding to the increased potency of DHT (11-13).

In addition to its well-characterized ability to function as a transcription factor as outlined above, the AR also signals through DNA-binding-independent mechanisms and can even signal in a ligand-independent fashion (14). Activation of non-classical (NC) AR rapidly affects the regulation of other nuclear receptors, transcription factors, and cytoplasmic signaling events including the release of intracellular calcium and the formation of inositol 1,4,5-triphosphate (15). NC receptors may be located in the plasma membrane, where they are associated with G-protein coupled receptors and subject to internalization, or in the cytoplasm $(16,17)$ [reviewed in Ref. $(18,19)]$. NC ARs include receptors that bind androgen either directly or indirectly via the steroid hormone binding globulin (SHBG) $(20,21)$. Finally, in the context of cancer, AR may be activated by a variety of growth factors independently of androgens (14).

Polymorphisms in the AR gene, NR3C5, are known to influence androgen signaling strength. The most widely studied polymorphism affects the number of CAG repeat sequences in exon one of the AR gene. Specifically, AR's transactivational activity decreases with the presence of longer CAG repeats and vice versa $(22,23)$. Interestingly, women with shorter CAG repeats (i.e., those with more potent AR signaling) exhibit higher androgen levels, while men with shorter CAG repeats experience more dramatic reductions in testosterone as they age $(24,25)$, suggesting that CAG repeats differentially affect AR signaling in men and women.

The expression of AR in various immune organs and multiple immune cells provides some indication of the level at which androgens influence immunity (Table $\mathbf{1}$ ). For example, T cells are sensitive to androgens throughout development and beyond, while B cells are primarily sensitive during development. Indeed, thymocytes and thymic epithelial cells express intracellular AR (26-28) as do peripheral T cells, which also express NC, membrane associated receptors $(17,28)$. Bone marrow stromal cells and B cell precursors, but not peripheral B cells, express AR (29-31). Gene expression studies show that the AR is expressed by all myeloid progenitor cells as well as some terminally differentiated cells of myeloid lineage, including neutrophils, monocytes,
TABLE 1 | Expression of androgen receptor (AR) in hematopoietic cells.

\begin{tabular}{llr}
\hline Cell type & AR expression (method) & Referen \\
\hline $\begin{array}{l}\text { Stem cells and progenitor cells } \\
\text { Hematopoietic stem cell }\end{array}$ & Yes (RT-PCR, IF) \\
Common myeloid progenitor & Yes (RT-PCR) \\
Common lymphoid progenitor & Yes (RT-PCR) \\
Granulocyte-macrophage progenitor & ND & $(33,34)$ \\
Common dendritic cell (DC) & ND \\
progenitor & \\
Megakaryocyte-erythroid progenitor & ND \\
Erythroblast & Yes (binding assay) \\
Early T cell progenitor & ND
\end{tabular}

Myeloid-derived cells

Megakaryocyte

Platelet

Erythroid cell (nucleated and

enucleated)

Monocyte

Macrophage

Myeloid-derived DC

Myelocyte

Metamyelocyte

Neutrophil (band cell)

Neutrophil (segmented)

Mature eosinophil

Basophil

Yes (IHC, RT-PCR, IF)

$(37,38)$

Yes (IF)

(38)

Not expressed $(\mathrm{IHC})$

(37)

Mature mast cell

Yes (RT-PCR)

(37)

Yes $(\mathrm{C}+\mathrm{NC})$ (flow, IF, IHC, $\quad(16,36,37$,

RT-PCR)

39)

Not expressed (WB)

Yes $(\mathrm{IHC})$

Yes $(\mathrm{IHC})$

Yes $(\mathrm{IHC})$

Yes $(\mathrm{IHC})$

Not expressed (IHC)

ND

Yes (ImmGold)

Lymphoid-derived cells

DN T cell

DP T cell

Yes (binding assay)

Yes (binding assay)

Yes (C+NC) (flow, IF,

binding assay)

CD8+ T cell

Yes (C+NC) (binding assay)

ND

Plasmacytoid DC

Pro-B cell

Pre-B cell

Immature B cell

Mature B cell

Yes (WB)

Yes (WB)

ND

Not expressed

(IHC, WB)

(37)

(37)

(37)

(37)

(37)

$(35,41)$

\section{Other}

Thymic epithelial cells

Bone marrow stromal cells

Yes (IF)

Yes $(\mathrm{IHC}, \mathrm{WB})$

ND, not determined; C, classical; NC, non-classical. ImmGold, ImmunoGold staining; $R T-P C R$, reverse-transcriptase-polymerase chain reaction; WB, western blotting; IF, immunofluorescence; IHC, immunohistochemical staining; flow, flow cytometry.

and macrophages $(16,32-36)$. Thus, there is great potential for androgen modulation of the development and function of both the lymphoid and myeloid branches of the immune system.

\section{ANDROGENS AND IMMUNE CELL SUBSETS}

There is ample evidence that androgens alter immune cell development and immune activation. In the following section, we review the effect of androgens on specific immune cell subsets and the potential effect this may have on immune responses and immune homeostasis in general. 


\section{Myeloid Cells}

The innate immune system consists of a number of different cell subsets, predominantly of myeloid origin. Most myeloid cells initiate their track of differentiation from hematopoietic stem cells in the bone marrow only to undergo final differentiation at sites of infection or inflammation. As mentioned above, all myeloid progenitor cells express the classical $\operatorname{AR}(34,35)$ and testosterone has been shown to affect early myelopoiesis (45-47). Myeloid cell-specific effects of androgens are further discussed below.

\section{Neutrophils}

Several lines of evidence suggest that androgens directly promote the differentiation of neutrophils from myeloid progenitors. For example, both genetically manipulated AR-deficient mice and androgen insensitive mice carrying the naturally occurring testicular feminization mutation $(\mathrm{t} f \mathrm{~m})$ exhibit neutropenia $(45,46)$. Similarly, androgen-deficient prostate cancer patients and gonadectomized male mice also display neutropenia, prior to androgenreplacement therapy/DHT treatment $(48,49)$. Further support for androgen-induced granulopoiesis and neutrophil differentiation comes from studies of stanozolol, a testosterone analog, showing an increased prevalence of myelocytes and metamyelocytes as well as accelerated neutrophil maturation in treated female mice (50). Neutrophilia can also be observed in young women with hyperandrogenism due to polycystic ovarian syndrome (47). Interestingly, treatment with the anti-androgen, flutamide, and metformin (known to reduce circulating levels of androgens) decreases numbers of neutrophils in these patients (47). Together, these studies suggest that androgens drive neutrophil differentiation and/or survival in mice and humans.

Although, less well understood, there is growing evidence that androgens might also affect neutrophil function. For example, testosterone suppresses both the anti-microbial activity and the production of pro-inflammatory cytokines by human neutrophils, while promoting the production of the anti-inflammatory cytokine IL-10 $(51,52)$. It is interesting that there are no reports of elevated numbers of myeloid cells in athletes taking anabolic androgenic steroids (AAS) as performance enhancing drugs, although increased production of pro-inflammatory cytokines (IL-1 $\beta$ and $\mathrm{TNF} \alpha$ ) and greater oxidative stress responses in PBMCs from AAS users [reviewed in Ref. $(53,54)]$ do suggest an effect on myeloid cell activity. In summary, androgens appear to promote neutrophil differentiation in mice and humans and may also dampen the inflammatory potential of mature neutrophils.

\section{Monocytes/Macrophages}

Both monocytes and macrophages have been found to express classical as well as $\operatorname{NC~} \operatorname{AR}(16,37,39,41)$. Testosterone treatment was shown to elevate levels of circulating monocytes in a population of type II diabetic men with partial androgen deficiency (55), however, whether this effect was due to augmented differentiation of monocytes in the BM or altered trafficking patterns remains unknown. Studies evaluating the importance of androgens and/or AR in macrophages during wound healing have shown that AR deficiency accelerates wound healing, while DHT treatment improves the quality of the wound by increasing collagen fibers $(56,57)$. It remains to be determined at which stages of wound healing testosterone/DHT binding to the AR is required, which may explain these seemingly contradictory results. Finally, gonadectomy has been found to drive increased TLR4 expression by male murine macrophages leading to elevated pro-inflammatory responses during infection (58), suggesting that one mechanism by which androgens are immunosuppressive is by limiting myeloid cell responsiveness to pathogens. This observation is further supported by data showing higher TLR4 expression, increased phagocytosis, and enhanced oxidative burst in female macrophages (59) and a specific downregulation of TLR4 expression by testosterone in vitro (58). Interestingly, male mice subjected to sepsis fare worse than females (60), although whether the outcome is dependent on testosterone-mediated suppression of myeloid cell activity remains unknown.

At the molecular level, studies have identified the presence of plasma membrane-located G-protein receptor coupled NC ARs on macrophages. These receptors are capable of binding testosterone either directly or bound to SHBG and elicit nontranscriptional stimulatory effects, such as rapid intracellular calcium mobilization and ERK phosphorylation (16, 20, 21). More research is needed to fully understand the impact of NC $\mathrm{AR}$ activation on macrophage function in males and females.

\section{Other Myeloid-Derived Cell Subsets Mast Cells}

Skin residing mast cells have been found to express the AR, however, neither numbers nor distribution of these cells are affected by altering levels of androgens $(35,41)$. Instead, mast cell function, as determined by histamine release, may be regulated by androgens, as histamine levels at some peripheral sites are reduced after castration (61). More recently, it was shown that at least under some circumstances testosterone directly induces Il33 expression by mast cells (62). Interestingly, IL-33 drives the generation of both innate lymphoid cells and basophils, known to produce Th2-associated cytokines and promote antibody class switching to IgE; an immunoglobulin found to be increased in young males over females in individuals suffering from allergic rhinitis $(63,64)$. Future studies will determine if androgens drive activation of other mast cell-specific proteins and processes.

\section{Eosinophils}

In contrast to neutrophils, numbers of eosinophils increased in the periphery and in the bone marrow of gonadectomized male mice (65). Castration did not, however, affect eosinophil numbers within sites of exposure, as eosinophil counts in nasal mucosa of unmanipulated and castrated male mice challenged with phospholipase A2 and Schistosoma mansoni egg antigen were comparable (66). Interestingly, testosterone directly reduced human eosinophil viability and adhesion properties in vitro (67), and DHEA suppressed eosinophil trafficking to the lung during infection (68), suggesting that androgens affect eosinophil numbers via control of tissue infiltration rather than de novo differentiation in the bone marrow. Additional studies evaluating the effect of the non-aromatizable DHT are needed to firmly address the role of $\mathrm{AR}$ and androgens on eosinophil maturation and function. 


\section{Basophils}

Basophils are largely unaffected by testosterone treatment (69) and expression of AR by these cells has not been determined.

\section{Dendritic Cells (DCs)}

At the border of the innate and the acquired immune systems, reside DCs. These can originate from either myeloid or lymphoid progenitors. Only few studies have investigated the effect of androgens on DC differentiation and function but overall, testosterone has been assigned an immunoinhibitory function. It remains controversial, however, whether this effect is direct or indirect, as at least one study demonstrated a lack of AR expression in myeloid-derived DCs (40). Nevertheless, exogenous DHT treatment has been found to either downregulate surface levels of MHC/HLA and costimulatory molecules or inhibit cytokine production in animal models resulting in reduced $\mathrm{T}$ cell activation, proliferation, and differentiation. For example, after LCMV infection, infiltrating DCs isolated from the brains of male mice were less activated (reduced MHC-II and CD86 expression) than cells isolated from females and gonadectomized male mice (70). This observation was due to testosterone, as DHT treatment of gonadectomized male mice reversed the DC phenotype back to that of intact males (70). Similarly, gonadectomy studies have shown that removal of testicular testosterone production in male mice results in increased expression of $\mathrm{MHC}$ and costimulatory molecules on DC (71). A similar pattern is found in hypogonadal men, in whom DC activation markers are significantly elevated, but reversed in response to exogenous testosterone treatment (72). The in vivo nature of these experiments and observations, however, do not necessarily support a direct effect of androgens on DCs, as both MHC and costimulatory molecules are also regulated by cytokines secreted by other cells subject to androgenic regulation. Specifically addressing this concern, bone marrowderived DCs, exposed briefly to DHT during antigen uptake, have been found to be less efficient $\mathrm{T}$ cell activators in vitro than BMDCs not exposed to DHT (73).

\section{Lymphoid Cells B Cells}

It has been known for decades that the average female produces higher levels of antibodies in response to infections and vaccinations [reviewed in Ref. (74)]. A number of studies have found strong correlations between low testosterone and elevated numbers of B cells (75-79), and high testosterone levels in men correlates with poorer antibody responses to vaccination (80), suggesting that androgens inhibit B lymphopoiesis. Recent studies of B cell subsets in 3- to 8-year-old children identified different distributions in males and females $(81,82)$. Specifically, boys demonstrate elevated levels of immature CD5+ B cells, while girls exhibit more memory-type B cells. Lundell et al. further evaluated levels of DHT in these children and found a positive correlation between DHT levels at birth and the frequency of immature B cells. Given the minimal exposure to exogenous agents, these data suggest that males and females are subject to differential genetic- and/or hormonal-driven gestational regulation of B cell lymphopoiesis.
In mouse studies, gonadectomy of male mice has been found repeatedly to drive $\mathrm{B}$ cell lymphopoiesis in the bone marrow, with both testosterone and DHT treatment capable of reversing this effect $(43,83,84)$. Similarly, global AR-deficient mice present with elevated $\mathrm{B}$ cell precursors in the bone marrow (pro-B stage and beyond) and studies of the B cell repertoire in B cell-specific AR knockout animals suggest that the lymphopoietic effect of testosterone is AR-dependent and intrinsic to the B cell-at least at the later stages of B cell development (pre-B cells and beyond) (85). However, other studies have suggested that the inhibitory effect of testosterone on B lymphopoiesis is dependent on bone marrow stromal cells $(29,30)$. Recently, AR expression by bone marrow osteoblasts was found to specifically inhibit early $B$ lymphopoiesis resulting in an accumulation of pro-B cells (86). Thus, it is likely that the differentiation of pro-B cells from common lymphoid progenitors is inhibited by AR expression by osteoblasts, while further differentiation along the B cell lineage is negatively affected by $\mathrm{AR}$ expression by the $\mathrm{B}$ cell progenitors themselves. A possible mechanism of action has been suggested based on studies showing that testosterone upregulates TGF $\beta$ production by bone marrow stromal cells leading to inhibition of IL-7 production and suppression of B lymphopoiesis $(29,87)$. In summary, B lymphopoiesis is inhibited by androgens both directly and indirectly via effects on bone marrow stromal cells.

\section{T Cells}

Thymic size and the selection of developing thymocytes is significantly affected by androgens. Testosterone deficient or insensitive males, due to gonadectomy or AR deficiency, experience thymic enlargement $(27,88-93)$. Thymic size returns to normal when gonadectomized males are treated with DHT (91). Studies involving AR-deficient bone marrow chimeric mice demonstrated that androgen signaling through AR in thymic epithelial cells mediates androgen's effects in the thymus (27). A similar observation was made in thymic epithelial cell-specific AR-/mice (94). In addition, androgens limit the numbers of CD4+ CD8+ and CD4+ CD8- in favor of CD4- CD8+ thymocytes, perhaps by suppressing proliferation and accelerating the apoptosis of immature thymocytes $(88,90,95,96)$. Finally, androgens enhance the negative selection of self-reactive $\mathrm{T}$ cells by upregulating the expression of autoimmune regulator (Aire) in medullary thymic epithelial cells (97). Androgens may also influence $\mathrm{T}$ cell development in tolerance-promoting ways by enhancing TGF- $\beta$ production in the thymus (98).

Similar to its effect on thymic size, androgens also limit the total number of $\mathrm{T}$ cells residing in the periphery. Postpubescent gonadectomized male mice exhibit larger peripheral lymphoid organs housing a greater number of lymphocytes, including both CD4+ and CD8+ T cells $(92,99)$. The expansion of peripheral lymphoid organs after the removal of androgens may be related to increases in thymic output and/or lessened peripheral $\mathrm{T}$ cell death, as an in vitro study recently demonstrated that DHT can non-selectively induce cell death in peripheral T cells (100).

Androgens are likely responsible for some portion of the effect of sex on peripheral T cell responses. Thymocytes and lymphocytes isolated from non-autoimmune female mice respond more vigorously to exogenous and allogeneic antigens in vitro than cells 
isolated from male mice $(101,102)$. Treating female mice with testosterone reduces the proliferative $\mathrm{T}$ cell response to OVA and KLH (101). Similarly, gonadectomized male mice, compared to intact male mice, proliferate more vigorously in response to TCR stimulation and OVA in vitro and in vivo $(92,99)$.

Cytokine production evoked by specific antigens are also often affected by sex, with male cells favoring Th2 type responses and female cells favoring Th1 type responses (92). For example, anti-CD3 stimulation provokes the secretion of Th2 cytokines, IL-10 and IL-4, from CD4+ T cells isolated from male experimental autoimmune encephalomyelitis (EAE)-prone SJL mice, but IL-12 from cells isolated from females (26). Interestingly, the addition of DHT to T cell cultures is sufficient to upregulate IL-10 expression (26). Beyond its ability to enhance the production of Th2 cytokines, androgens actively inhibit Th1 differentiation $(103,104)$, by inhibiting IL-12 and IFN- $\gamma$ production downstream of antigen stimulation (105-109).

Androgens may influence the differentiation and function of regulatory $\mathrm{T}$ cells differently in males versus females. In vivo androgen supplementation of women with adrenal insufficiency and female rats with experimental autoimmune orchitis expands the number of regulatory T cells $(104,110)$. More specifically, when bound to ligand, the AR directly enhances the expression of Foxp3 in T cells (regulatory or otherwise) isolated from rats or women during the ovulatory phase, but not men (111). Thus, androgens are capable of directly converting peripheral $\mathrm{T}$ cells into regulatory $\mathrm{T}$ cells in women. By contrast, androgens may interfere with regulatory $\mathrm{T}$ cell function in men, as occurs in a mouse model of Sjögren's syndrome that predominantly affects male mice (112).

Overall, androgens directly influence the development of lymphoid cells; and at least in mice, lymphoid cells that develop in the presence of androgens may retain differential characteristics even when later placed in an androgen-deficient environment. Moreover, androgens appear to suppress the inflammatory potential of peripheral lymphoid cells. In some cases, such effects may be direct, but the absence of AR in peripheral B cells, for example, suggests that differences are more likely due to prior exposure to androgens during development, or regulation by other androgen-sensitive peripheral cells.

\section{ANDROGENS IN AUTOIMMUNITY}

Many autoimmune disorders are more prevalent in females, including autoimmune thyroiditis, systemic lupus erythematosus (SLE), Sjögren's syndrome, multiple sclerosis (MS), and rheumatoid arthritis (RA) (113). Both sex hormones and genes expressed on the $\mathrm{X}$ or $\mathrm{Y}$ chromosomes have been proposed to drive this bias, as exemplified by the fact that Klinefelter's patients (XXY karyotype) express not only two X chromosomes but also reduced levels of androgens, and present with an increased risk for most of these disorders (114). Many patients of either sex with autoimmune disorders that predominantly affect women also demonstrated lower serum concentrations of androgens $(76,115,116)$. Here, we will discuss the influence of androgens on the development and severity of RA, MS, and SLE.

\section{Rheumatoid Arthritis}

Rheumatoid arthritis is characterized by synovial inflammation and swelling, as well as cartilage and bone destruction. Some patients may develop one or more additional systemic sequelae, including cardiovascular disease, pulmonary disorders, lymphoma, lung cancer, psychological disorders, and osteoporosis (117). Like many other autoimmune diseases, RA is $2-4$ times more frequent in women than in men (113). Most studies have concluded that in addition to increased susceptibility, female RA patients suffer from a more severe version of the disease, with higher disease activity scores, faster progression, more pain, and lower remission rates (118-122).

While estrogens likely contribute to the increased female risk of RA (123), it has been hypothesized that androgens may also offer some protection from the disease. Indeed, serum androgen levels tend to be lower in men with RA as compared to healthy controls. For example, the incidence of RA increases as androgen production declines in aging men and several groups have reported lower serum testosterone concentrations in male RA patients as compared to controls $(76,124-130)$. Furthermore, men who experience a dramatic loss of serum androgens with age may develop a more aggressive form of RA with earlier onset (131-133). In some cases, low serum androgens also correlate with increased risk of developing RA. Men with genetic hypogonadism (Klinefelter's syndrome) and prostate cancer patients treated with androgen-ablating therapy are at increased risk of developing RA $(114,134)$.

Interestingly, serum androgen levels are not lower prior to the onset of RA in all patients, suggesting that low androgens are not universally predisposing to the development of RA $(127,133)$. Instead, as a recent large study reported, men with lower serum testosterone levels prior to the onset of RA may be more likely to develop a specific subset of RA, characterized as rheumatoid factor negative (135). It is possible that the correlation of low serum androgen levels and RA in men can be explained by inflammatory cytokines, such as IL-6, which become elevated during the disease process and are known to suppress the secretion of adrenal androgens (136). The notion that low serum androgens are a consequence of RA, as opposed to a cause in some cases, is supported by an inverse correlation between low free testosterone and inflammatory markers and disease activity $(129,137)$, as well as the finding that successful treatment of RA correlates with the restoration of normal levels of free testosterone (130). To summarize, androgens may protect against the development of RA in men in some circumstances; and in others, the inhibition of androgen secretion by the RA-inflammatory response is secondary to RA, but may still influence the severity of disease in men.

The effect of androgens on RA susceptibility and severity in women is less well understood. Androgens may protect against RA in some women, but other studies suggest that androgens may actually worsen disease severity. As in men, low serum concentrations of androgens, particularly DHEA and/or DHEA-S, are linked with RA in women $(136,138-140)$. However, as was found in men, serum androgen levels are within the normal range 10 years prior to the onset of RA and levels of DHEA-S inversely correlate with disease duration and severity in women $(127,140)$. 
Thus, for most female patients, the inhibitory effect of inflammation on the secretion of androgens may explain this correlation. Two notable exceptions to this include women who inherited particular polymorphisms resulting in higher or lower androgen levels correlating with protection from disease or exacerbation, respectively. First, women predisposed to produce androgens in greater concentrations due to inheritance of a polymorphism in the CYB5A gene are protected from developing RA characterized by RF and antibodies to citrullinated proteins (141); and, second, women with lower serum androgens are more likely to develop a type of RA that is not responsive to combination therapy consisting of nonsteroidal anti-inflammatory drugs, low-dose prednisolone, methotrexate, and more than one of several other disease modifying anti-rheumatic drugs (142).

In contrast to the above findings, high androgen concentrations or more potent AR signaling have been reported in some women with more severe RA. For example, one small study reported normal androgen concentrations in premenopausal RA patients, and higher testosterone and DHEA-S in postmenopausal women with RA (143). More strikingly, women with higher concentrations of serum androgens due to a low number of CAG repeats in the AR developed a more aggressive RA with earlier onset, though overall susceptibility to RA was not affected (131-133, 144).

Because of the correlation between low serum androgens and RA and the known immunosuppressive properties of androgens, androgens have been utilized to some extent as a treatment for RA. Overall, the administration of androgens to male and female patients had a positive effect for both sexes (145-148). However, it should be noted that such studies are few in number, with small patient populations, short-term treatments, modest improvements, and in some cases, no effect at all.

\section{Animal Models of RA}

Several animal models of RA also show increased susceptibility or more severe disease in females as compared to males (149-152). For example, the incidence of RA is greater or more severe for females in collagen-induced arthritis (CIA) in rats, SKG mice injected with zymosan, LEW/N rats injected with polysaccharide fragments from group A streptococcal bacteria, and BALB/c mice with cotton-pellet induced inflammation (149-152). Moreover, androgens have been shown to exert protective effects in $\mathrm{RA}$, even in animal models with equal or more severe disease in males $(150,153)$. Gonadectomy of male animals worsens RA in CIA-rats and SKG mice; and, the addition of DHT to gonadectomized CIA-rats inhibits disease $(149,152)$. Male and female rats injected with complete Freund's adjuvant (adjuvant arthritis) do not demonstrate a sex bias; however, similar to human studies, arthritic males demonstrate lower testosterone levels after disease induction (153). Finally, the expression of the AR on B cell progenitors has been shown to have protective effects in male mice with CIA (150).

\section{Cellular and Molecular Targets of Androgens in RA}

Regardless of whether serum androgen levels or receptor activity is involved in systemic RA etiology, a separate case has been made for its involvement in disease pathogenesis within affected joints.
The synovial fluid of RA patients exhibits elevated levels of free estrogens and reduced concentrations of free androgens, possibly due to increased local aromatization of androgens to estrogens (154). The conversion of androgens to estrogens heightens the local inflammatory response, since androgens have been shown to inhibit the synthesis and secretion of IL-1 and IL-6, two important inflammatory cytokines in RA (155-158). The relationship between androgens, inflammatory cytokines, and aromatase activity is reciprocal; IL1 and IL6 stimulate aromatase activity, while androgens inhibit it (157).

In summary, with some notable exceptions, the correlation between low androgen and RA likely exists because RA-associated inflammation dampens serum androgen levels. Improvements in our ability to group RA into less heterogenous disease subgroups may reveal particular subgroups that are more affected by androgen levels than others.

\section{MS and Androgens}

Multiple sclerosis is an autoimmune disorder in which neuronal axons are actively demyelinated leading to neuronal damage and eventual paralysis. The disease precipitates in patterns of relapsing-remitting or progressive-onset. Only the former of these shows a sex-bias; relapsing-remitting MS (RRMS) develops 3-4 times more frequently in females than in males and predominantly in individuals of childbearing age, suggesting a role for sex hormones [reviewed in Ref. (159)]. In addition to higher incidence rates among female RRMS patients, many studies have also shown that women exhibit higher relapse rates than men (160-165), further supporting a gender-bias in this disease. Several studies have evaluated levels of sex hormones in MS patients, and testosterone, DHEA, or DHEA-S levels have been found to be lower in both men and women with MS as compared to healthy age-matched controls $(115,165-168)$. Although it is generally thought that testosterone's protective effect is mediated via immune modulation, treatment with testosterone improved cognitive performance and slowed brain atrophy (169) and has been suggested to increase gray matter in a small cohort of men with RRMS, suggesting a direct neuroprotective function of testosterone (170).

Multiple sclerosis patients display a chronic inflammatory profile characterized by $\mathrm{T}$ cell-derived cytokines (IFN $\gamma$ and IL-17) and circulating antibodies reactive to brain autoantigens (171-176). Both T cell and B cell differentiation and effector functions have been shown to be affected by androgens (as mentioned above), however, clinical trials with drugs specifically targeting IL-17A (secukinumab) or B cells (rituximab) were only somewhat effective $(177,178)$, and targeting IFN $\gamma$ via blockade of IL-12 (ustekinumab) was not effective (179).

\section{Animal Models of MS}

Studies of EAE (animal model of MS) have largely confirmed a protective role for androgens (180-183). For example, gonadectomy of male SJL mice resulted in increased disease susceptibility, while treatment with exogenous testosterone or DHT reduced disease incidence in both females and males $(180,181)$. Although C57Bl/6 male and female mice develop EAE at a similar rate, $\mathrm{C} 57 \mathrm{Bl} / 6$ male mice were also protected by treatment with DHT (181), 
and similar results have been obtained in EAE-susceptible Dark Agouti rats (183). By contrast, Ziehn et al. showed that only testosterone, not DHT, exerted a direct neuoprotective effect (182), suggesting that testosterone and DHT may have independent effects on cells of the hippocampus and infiltrating immune cells. Further studies are needed to thoroughly investigate if AR binding is required for the protective effect of androgenic treatment.

\section{Cellular and Molecular Targets of Androgens in MS/EAE}

While most studies support an overall protective effect of testosterone in MS and EAE, specific immunological targets are less well explored. Androgens may affect $\mathrm{T}$ cells in at least two specific ways. As mentioned above, androgens stimulate the Aire promoter, driving increased Aire expression by medullary thymic epithelial cells and increased negative selection (97). As a result hereof, male mice or mice treated with DHT are relatively protected from EAE (97). Second, EAE is typically driven by T helper cells (Th1 and Th17) and is characterized by the presence of key signature cytokines such as IFN $\gamma$ and IL-17 within the brain, secondary lymphoid organs, and circulation. A general Th1 propensity has been observed in female patients with MS and EAE animal models (184-187) and it has been suggested that low levels of testosterone drive this phenotype. In support hereof, ex vivo exposure of encephalomyelitic $\mathrm{T}$ cells to testosterone has been shown to significantly change the secreted cytokine profile (from IFN $\gamma$ to IL-10) and the pathogenic potential of these T cells $(180,188)$. Furthermore, myelin-basic protein-primed female $\mathrm{T}$ cells and $\mathrm{T}$ cells from gonadectimized males express significantly higher levels of the VLA- 4 integrin $\beta 1$ subunit and secrete higher levels of pro-inflammatory cytokines, such as IL-1 $\beta$, than male-derived cells (189), thereby promoting $\mathrm{T}$ cell infiltration into the brain and brain pathogenesis. Although the mechanism driving differential $\mathrm{T}$ cell activation in males and females is largely unknown, Dunn et al. recently described that PPAR $\alpha$ was highly expressed in male $\mathrm{T}$ cells in a testosterone-dependent manner and that deficiency of PPAR $\alpha$ specifically worsened EAE in male mice (109). Further studies are needed to establish the interrelationship between PPAR $\alpha$, Aire, and other DHT-dependent immune regulators.

In conclusion, low levels of androgens are observed in patients with MS and gonadectomy of male mice increases their susceptibility to induced EAE. T cells have been found to respond to androgens throughout development and recent studies have started to unravel molecular mechanisms associated with androgeninduced $\mathrm{T}$ cell suppression.

\section{Androgens in SLE}

Systemic lupus erythematosus, a chronic and potentially fatal disease with the potential to cause damage in multiple organ systems, is nine times more prevalent in women than men (190). Physicians commonly see patients with a wide range of clinical manifestations, which may spontaneously flare and remit. For example, patients with mild lupus may present with intermittent skin rash and joint pain and require little medication, while patients with severe glomerulonephritis may show progressive renal deterioration despite treatment with high doses of corticosteroids and cytotoxic drugs. Other significant health consequences can include central nervous system involvement, vasculitis, thrombosis, thrombocytopenia, anemia, fevers, fatigue, and heart and lung involvement $(190,191)$.

Antinuclear autoantibodies (ANAs) are generally considered to be a hallmark of lupus $(190,191)$. A portion of the tissue damage in SLE is related to autoantibodies that target cell surface antigens. In other cases, such as in the kidney, the deposition, or in situ formation of ANA immune complexes with subsequent complement activation and inflammatory cell recruitment are responsible for the damage. The damage generated by immune complexes is not trivial; SLE is a leading cause of kidney disease, stroke, and premature cardiovascular disease in young women $(192,193)$.

A number of reports have suggested that androgens are protective in SLE. Although many male lupus patients have normal levels of androgens (194), men with hypogonadism are at increased risk of developing SLE $(114,116,195)$ and testosterone supplementation of male lupus patients with genetic hypogonadism (Klinefelter's syndrome) has, in two cases, been beneficial in treating lupus $(196,197)$. However, no large-scale studies involving testosterone supplementation in male lupus patients have been reported (198). Women with lupus generally have lower androgen levels, including testosterone, DHT, DHEA, and DHEA-S (199-201), and demonstrate an accelerated inactivation of testosterone via oxidation than healthy age-matched controls (202). In addition, it has been suggested that inflammatory cytokines in affected tissues modulate aromatase activity to locally dampen the effects of androgens in favor of estrogens in lupus patients (203). Finally, male lupus patients with reduced AR signaling produce higher quantities of IgG autoantibodies (204), while female lupus patients with the same polymorphism exhibited reduced disease (78). It is not clear why reduced androgen signaling is associated with opposite effects on lupus in male and female patients. However, recent studies in the BWF1 animal model (discussed below) have also identified instances whereby androgen-mediated mechanisms of disease suppression are not effective in females (48). Together these observations suggest that androgens affect lupus pathogenesis differently in males and females and that the mechanisms by which androgens limit disease may not be immediately applicable as therapies for female patients.

Although survival rates of male lupus patients are comparable to survival rates in female lupus patients (205-210), it has been reported that the severity of SLE is worse in males than in females, suggesting that genetic susceptibility must be more potent in men to overcome the protection afforded by androgens (211-215). This is supported by reports that male lupus patients have an increased frequency of renal involvement $(208,210$, 216-218) and that women with an affected male relative are 3.5 times more likely to develop renal disease than women without an affected male relative (219).

Some effort has been made to treat lupus with androgenic compounds. The small numbers of patients included in many of the following clinical trials make definitive conclusions difficult. However, in general, these studies support an ameliorating role for androgens. Danazol, a weakly androgenic synthetic compound, 
reduced total serum IgG as well as anti-dsDNA autoantibody levels in women $(220,221)$. However, all patients did not benefit from therapy and some experienced disease flares $(220,221)$. Likewise, treatment with a testosterone-like anabolic steroid, nandrolone, afforded some patients clinical improvement, but other patients saw no improvement and masculinizing side effects made this drug a somewhat untenable treatment option for most women $(202,222,223)$.

Larger clinical trials have been conducted with DHEA, an adrenal steroid with mild androgenic activity, in the hopes of separating the disease-ameliorating properties of androgens from its masculinizing ones. However, as for other androgenic drugs, some patients treated with DHEA (also known as prasterone) experienced reduced disease activity, improved cognitive function, enhanced mental well-being, and a reduced need for corticosteroid treatment (224-228), while others experienced no improvement $(229,230)$. Overall, treatment with this agent did not meet primary objectives of these studies and it has not been approved by the Federal Drug Agency for treatment of lupus patients. It should be mentioned that in a recent study, female lupus patients with a particular polymorphism in the extra-pituitary prolactin gene associated with low serum DHEA levels experienced the most dramatic improvements after DHEA treatment (201). Thus, genetic differences of particular study populations may explain the varied results from different clinical trials with DHEA in lupus patients.

\section{Androgens in Mouse Models of Lupus}

Inbred mice that spontaneously develop a lupus-like disease have been extremely helpful toward elucidating the etiology and pathogenesis of lupus. Several spontaneous models of lupus exist [reviewed in Ref. (231)]. Here, we focus exclusively on studies conducted with the F1 offspring of New Zealand black (NZB) and New Zealand white (NZW) mice. The female F1 offspring of NZB and NZW mice (BWF1) develop a lupus-like disease characterized by high levels of IgG ANAs accompanied by a severe and progressive glomerulonephritis in the first year of life $(232,233)$. By contrast, less than half of BWF1 male mice develop severe proteinuria within the same time period $(232,233)$. As in humans, several studies have determined that androgens suppress lupus pathogenicity BWF1 mice. For example, prepubescent gonadectomy of BWF1 male mice increases the incidence of proteinuria and mortality and accelerates the appearance of ANAs as compared to intact males (233-235). In addition, administration of DHT to gonadectomized male mice is sufficient to reduce disease development comparable to that observed in intact male mice (233-235).

Chemicalmanipulation of androgensinlupus-proneBWF1 mice also generally supports the hypothesis that androgens are protective in lupus. For example, treatment of BWF1 females with nandrolone decanoate (236-238) and ethylestrenol (239), which are both testosterone-like anabolic steroids, ameliorated disease. Nandrolone decanoate also reduced IgG anti-dsDNA antibody, reduced the incidence of proteinuria, and improved survival $(236,238)$. Similarly, DHEA treatment significantly delayed disease onset, reduced IgG anti-dsDNA autoantibodies, and reduced mortality (240). By contrast, danazol did not protect BWF1 females from accelerated development of disease (241), and treatment of BWF1 females with the anti-androgenic drug, flutamide, resulted only in a slight decrease in survival, with no noticeable effect on autoantibody levels (242). Overall, BWF1 male and female mice recapitulate much of the sex bias observed in lupus patients and are a useful model for advancing our understanding of the role of androgens in lupus-like disease.

\section{Cellular and Molecular Targets of Androgens in Lupus}

Many autoimmune diseases that are more prevalent in females, including SLE, are characterized by increased numbers of B cells and circulating autoantibody levels [reviewed in Ref. (243)]. Some evidence suggests that androgens may indirectly regulate isotype switching from IgM to more pathogenic IgG autoantibodies in BWF1 mice. Serum testosterone levels dramatically drop in intact BWF1 males at 9 months of age (234), paralleling the time at which autoantibodies in intact males class switch to IgG $(233,244)$. Furthermore, treating 9-month-old BWF1 males with physiological levels of DHT greatly decreases mortality, prevents IgM anti-polyA antibodies from class switching to IgG, and reduces the levels of IgG anti-dsDNA antibodies (234). By contrast, DHT treatment in intact BWF1 female mice after autoantibody production (6 months) does not affect levels of IgG anti-dsDNA autoantibodies, although mortality is reduced (245). Though the mechanism by which androgens suppress disease in older mice remains unclear, some studies suggest that androgens enhance (and estrogens delay) immune complex clearance (246); a process frequently associated with the development of SLE and lupus in mouse models. For example, androgens have been shown to enhance serum levels of complement components C4, Slp, C5, C6, and Ss binding protein, which could underlie more efficient IC clearance (247-249). More current studies evaluating a relationship between androgens and complement has to our knowledge not been performed.

As indicated above, androgens have been shown to have discreet effects on $B$ cell function and downstream kidney damage in males and females. Androgens also appear to modulate the development and function of neutrophils differently in lupusprone males and female. We have previously shown that Gr1+ $\mathrm{CD} 11 \mathrm{~b}+$ cells accumulate in male mice, inhibiting the function of $\mathrm{T}$ follicular helper cells, germinal center formation, and plasma cell differentiation $(48,49,250)$. Interestingly, these myeloid cells suppress disease in male, but not female, mice. It is intriguing to speculate that perhaps the increased frequency of suppressive Gr1 + CD11b + cells in males is a related to CD11b+ cell overexpression of the DHT-regulated gene, colony-stimulating factor 3-receptor (Csf3-r) (233). Together with its ligand, G-CSF, CSF3-R is involved in maintaining neutrophil homeostasis and also regulates several aspects of neutrophil function (251). Interestingly, high doses of G-CSF suppress lupus-like disease in at least one animal model (252) and polymorphisms, the Csf3-r gene influence the development of lupus and RA $(253,254)$. Thus, it is not unreasonable to hypothesize that sex-specific alterations in expression of CSF3-R could influence neutrophil phenotype and function and thereby differentially influence lupus pathogenesis in males and females. Overall, at least in mice, it seems as though 
lupus pathogenesis may proceed in fundamentally different ways in male and female mice.

\section{CANCER AND ANDROGENS}

Immune cells must be capable of distinguishing modified-self from self, and yet, must not become unduly activated against unmodified self-antigens. Immune activity outside of these boundaries likely risks the development of cancer or autoimmunity and it follows that immune systems especially good at protecting against cancer may run the risk of triggering autoimmunity (and vice versa). Given that women are more susceptible to many autoimmune diseases, one might expect men to be more susceptible to cancer. Indeed, a number of epidemiologic studies and meta-analyses have recently confirmed that cancer develops more frequently in males than in females (255-257). In a meta-study examining mortality rates from 1977 to 2006, the male-to-female mortality-rate ratios were also found to be increased all malignant cancers, although predominantly for cancers affecting the upper gastro-intestinal tract and respiratory systems (lip, tongue, hypopharynx, esophagus, larynx, lung, etc.) as well as liver and bladder (255). Many factors have been proposed to explain this discrepancy including environmental exposures (smoking, obesity, infections) and sex hormone levels and signaling $(255,258)$.

As mentioned above, chronic inflammation can lead to suppression of testosterone. Cancer is known to induce a stage of chronic inflammation, and thus in order to study a potential causal relationship between testosterone and cancer development, retrospective cohort analyses investigating levels of testosterone prior to the diagnosis of cancer are necessary. Not many studies of that kind have been done. In one study, testosterone levels were found to positively correlate with the risk for a subset of epithelial ovarian cancers (259). Similarly, higher levels of testosterone correlated with an increased risk of breast cancer in women (260). It will be interesting to see if this pattern holds for other types of cancer.

\section{Animal Models of Cancer}

More direct evidence supporting a tumorigenic role for androgen in cancer development comes from animal studies, where

\section{REFERENCES}

1. Marchetti PM, Barth JH. Clinical biochemistry of dihydrotestosterone. Ann Clin Biochem (2013) 50:95-107. doi:10.1258/acb.2012.012159

2. Griffin JE, Wilson JD. The syndromes of androgen resistance. $N$ Engl J Med (1980) 302:198-209. doi:10.1056/NEJM198001243020404

3. Prough RA, Clark BJ, Klinge CM. Novel mechanisms for DHEA action. J Mol Endocrinol (2016) 56:R139-55. doi:10.1530/JME-16-0013

4. Simental JA, Sar M, Lane MV, French FS, Wilson EM. Transcriptional activation and nuclear targeting signals of the human androgen receptor. J Biol Chem (1991) 266:510-8.

5. He B, Kemppainen JA, Voegel JJ, Gronemeyer H, Wilson EM. Activation function 2 in the human androgen receptor ligand binding domain mediates interdomain communication with the $\mathrm{NH}(2)$-terminal domain. J Biol Chem (1999) 274:37219-25. doi:10.1074/jbc.274.52.37219

6. He B, Kemppainen JA, Wilson EM. FXXLF and WXXLF sequences mediate the NH2-terminal interaction with the ligand binding domain of the androgen receptor. JBiol Chem (2000) 275:22986-94. doi:10.1074/jbc. M002807200 susceptibility to cancer in response to chemicals and genetic manipulation often depend on sex hormone levels (261). For example, gonadectomy of male rats reduced both chemicalinduced pancreatic tumor burden (262) and renal cell carcinoma (263), while re-administration of testosterone at least partly reversed this effect. Furthermore, injection of prostate cancer cells into unmanipulated and gonadectomized nude male mice showed reduced tumor growth in gonadectomized mice and increased tumor growth upon subsequent testosterone treatment (94). It should be noted that whether these effects of testosterone were due to inhibition of immune activation or via direct effects on tumor cells remains to be tested. In a separate study of induced thyroid cancer in male mice, gonadectomy led to an upregulation of tumor-suppressor genes (264). With tumor-suppressor proteins present, CCL5 chemokine expression by tumor cells increased driving infiltration by inflammatory macrophages and CD8+ cytotoxic T cells and subsequently reduced tumor growth. Thus, testosterone may be predictive of increased cancer risk, warranting further research into the immunosuppressive and potential cancer-promoting effects of testosterone during early establishment of cancer.

\section{CONCLUDING REMARKS}

To conclude, sex-specific biases in autoimmunity and cancer incidence are associated with many differences in immune cell development and function. A significant portion of these differences are the result of exposure to androgens. Androgen-mediated suppression of immune reactivity and inflammation increases the threshold for autoimmunity to develop, but likely lowers the threshold for cancer. Studies further uncovering immune-specific effects of androgens are needed and may lead to the identification of pathways that could be targeted therapeutically to inhibit the incidence and progression of autoimmunity and cancer.

\section{AUTHOR CONTRIBUTIONS}

MGB and TNJ contributed equally to this project.

7. Loy CJ, Sim KS, Yong EL. Filamin-A fragment localizes to the nucleus to regulate androgen receptor and coactivator functions. Proc Natl Acad Sci U S A (2003) 100:4562-7. doi:10.1073/pnas.0736237100

8. Ozanne DM, Brady ME, Cook S, Gaughan L, Neal DE, Robson CN. Androgen receptor nuclear translocation is facilitated by the f-actin cross-linking protein filamin. Mol Endocrinol (2000) 14:1618-26. doi:10.1210/mend.14.10.0541

9. Cardozo CP, Michaud C, Ost MC, Fliss AE, Yang E, Patterson C, et al. $\mathrm{C}$-terminal Hsp-interacting protein slows androgen receptor synthesis and reduces its rate of degradation. Arch Biochem Biophys (2003) 410:134-40. doi:10.1016/S0003-9861(02)00680-X

10. Shatkina L, Mink S, Rogatsch H, Klocker H, Langer G, Nestl A, et al. The cochaperone Bag-1L enhances androgen receptor action via interaction with the NH2-terminal region of the receptor. Mol Cell Biol (2003) 23:7189-97. doi:10.1128/MCB.23.20.7189-7197.2003

11. Gaughan L, Logan IR, Neal DE, Robson CN. Regulation of androgen receptor and histone deacetylase 1 by Mdm2-mediated ubiquitylation. Nucleic Acids Res (2005) 33:13-26. doi:10.1093/nar/gki141

12. Haelens A, Tanner T, Denayer S, Callewaert L, Claessens F. The hinge region regulates DNA binding, nuclear translocation, and transactivation of the 
androgen receptor. Cancer Res (2007) 67:4514-23. doi:10.1158/0008-5472. CAN-06-1701

13. Lee DK, Chang C. Endocrine mechanisms of disease: expression and degradation of androgen receptor: mechanism and clinical implication. JClin Endocrinol Metab (2003) 88:4043-54. doi:10.1210/jc.2003-030261

14. Davey RA, Grossmann M. Androgen receptor structure, function and biology: from bench to bedside. Clin Biochem Rev (2016) 37:3-15.

15. Bennett NC, Gardiner RA, Hooper JD, Johnson DW, Gobe GC. Molecular cell biology of androgen receptor signalling. Int J Biochem Cell Biol (2010) 42:813-27. doi:10.1016/j.biocel.2009.11.013

16. Benten WP, Lieberherr M, Stamm O, Wrehlke C, Guo Z, Wunderlich F. Testosterone signaling through internalizable surface receptors in androgen receptor-free macrophages. Mol Biol Cell (1999) 10:3113-23. doi:10.1091/ mbc.10.10.3113

17. Benten WP, Lieberherr M, Giese G, Wrehlke C, Stamm O, Sekeris CE, et al. Functional testosterone receptors in plasma membranes of T cells. FASEB $J$ (1999) 13:123-33. doi:10.1096/fasebj.13.1.123

18. Boonyaratanakornkit V, Edwards DP. Receptor mechanisms mediating non-genomic actions of sex steroids. Semin Reprod Med (2007) 25:139-53. doi:10.1055/s-2007-973427

19. Durdiakova J, Ostatnikova D, Celec P. Testosterone and its metabolites modulators of brain functions. Acta Neurobiol Exp (Wars) (2011) 71:434-54.

20. Pi M, Parrill AL, Quarles LD. GPRC6A mediates the non-genomic effects of steroids. J Biol Chem (2010) 285:39953-64. doi:10.1074/jbc.M110.158063

21. De Toni L, Guidolin D, De Filippis V, Tescari S, Strapazzon G, Santa RM, et al. Osteocalcin and sex hormone binding globulin compete on a specific binding site of GPRC6A. Endocrinology (2016) 157:4473-86. doi:10.1210/ en.2016-1312

22. Chamberlain NL, Driver ED, Miesfeld RL. The length and location of CAG trinucleotide repeats in the androgen receptor $\mathrm{N}$-terminal domain affect transactivation function. Nucleic Acids Res (1994) 22:3181-6. doi:10.1093/ nar/22.15.3181

23. Tut TG, Ghadessy FJ, Trifiro MA, Pinsky L, Yong EL. Long polyglutamine tracts in the androgen receptor are associated with reduced transactivation, impaired sperm production, and male infertility. JClin Endocrinol Metab (1997) 82:3777-82. doi:10.1210/jcem.82.11.4385

24. Krithivas K, Yurgalevitch SM, Mohr BA, Wilcox CJ, Batter SJ, Brown M, et al. Evidence that the CAG repeat in the androgen receptor gene is associated with the age-related decline in serum androgen levels in men. J Endocrinol (1999) 162:137-42. doi:10.1677/joe.0.1620137

25. Westberg L, Baghaei F, Rosmond R, Hellstrand M, Landen M, Jansson M, et al. Polymorphisms of the androgen receptor gene and the estrogen receptor beta gene are associated with androgen levels in women. J Clin Endocrinol Metab (2001) 86:2562-8. doi:10.1210/jcem.86.6.7614

26. Liva SM, Voskuhl RR. Testosterone acts directly on CD4+ T lymphocytes to increase IL-10 production. JImmunol (2001) 167:2060-7. doi:10.4049/ jimmunol.167.4.2060

27. Olsen NJ, Olson G, Viselli SM, Gu X, Kovacs WJ. Androgen receptors in thymic epithelium modulate thymus size and thymocyte development. Endocrinology (2001) 142:1278-83. doi:10.1210/endo.142.3.8032

28. Benten WP, Becker A, Schmitt-Wrede HP, Wunderlich F. Developmental regulation of intracellular and surface androgen receptors in T cells. Steroids (2002) 67:925-31. doi:10.1016/S0039-128X(02)00055-7

29. Olsen NJ, Gu X, Kovacs WJ. Bone marrow stromal cells mediate androgenic suppression of B lymphocyte development. J Clin Invest (2001) 108:1697704. doi:10.1172/JCI200113183

30. Smithson G, Couse JF, Lubahn DB, Korach KS, Kincade PW. The role of estrogen receptors and androgen receptors in sex steroid regulation of $B$ lymphopoiesis. J Immunol (1998) 161:27-34.

31. Benten WP, Stephan C, Wunderlich F. B cells express intracellular but not surface receptors for testosterone and estradiol. Steroids (2002) 67:647-54. doi:10.1016/S0039-128X(02)00013-2

32. Claustres M, Sultan C. Androgen and erythropoiesis: evidence for an androgen receptor in erythroblasts from human bone marrow cultures. Horm Res (1988) 29:17-22. doi:10.1159/000180959

33. Igarashi H, Kouro T, Yokota T, Comp PC, Kincade PW. Age and stage dependency of estrogen receptor expression by lymphocyte precursors. Proc Natl Acad Sci U S A (2001) 98:15131-6. doi:10.1073/pnas.011513098
34. Mierzejewska K, Borkowska S, Suszynska E, Suszynska M, PoniewierskaBaran A, Maj M, et al. Hematopoietic stem/progenitor cells express several functional sex hormone receptors-novel evidence for a potential developmental link between hematopoiesis and primordial germ cells. Stem Cells $\operatorname{Dev}$ (2015) 24:927-37. doi:10.1089/scd.2014.0546

35. Sinha-Hikim I, Taylor WE, Gonzalez-Cadavid NF, Zheng W, Bhasin S. Androgen receptor in human skeletal muscle and cultured muscle satellite cells: up-regulation by androgen treatment. J Clin Endocrinol Metab (2004) 89:5245-55. doi:10.1210/jc.2004-0084

36. Wunderlich F, Benten WP, Lieberherr M, Guo Z, Stamm O, Wrehlke C, et al. Testosterone signaling in T cells and macrophages. Steroids (2002) 67: 535-8. doi:10.1016/S0039-128X(01)00175-1

37. Mantalaris A, Panoskaltsis N, Sakai Y, Bourne P, Chang C, Messing EM, et al. Localization of androgen receptor expression in human bone marrow. J Pathol (2001) 193:361-6. doi:10.1002/1096-9896(0000)9999:9999<::AIDPATH803> 3.0.CO;2-W

38. Khetawat G, Faraday N, Nealen ML, Vijayan KV, Bolton E, Noga SJ, et al. Human megakaryocytes and platelets contain the estrogen receptor beta and androgen receptor (AR): testosterone regulates AR expression. Blood (2000) 95:2289-96.

39. Sader MA, McGrath KC, Hill MD, Bradstock KF, Jimenez M, Handelsman DJ, et al. Androgen receptor gene expression in leucocytes is hormonally regulated: implications for gender differences in disease pathogenesis. Clin Endocrinol (Oxf) (2005) 62:56-63. doi:10.1111/j.1365-2265.2004.02173.x

40. Paharkova-Vatchkova V, Maldonado R, Kovats S. Estrogen preferentially promotes the differentiation of CD11c+CD11b(intermediate) dendritic cells from bone marrow precursors. J Immunol (2004) 172:1426-36. doi:10.4049/ jimmunol.172.3.1426

41. Chen W, Beck I, Schober W, Brockow K, Effner R, Buters JT, et al. Human mast cells express androgen receptors but treatment with testosterone exerts no influence on IgE-independent mast cell degranulation elicited by neuromuscular blocking agents. Exp Dermatol (2010) 19:302-4. doi:10.1111/ j.1600-0625.2009.00969.x

42. Kovacs WJ, Olsen NJ. Androgen receptors in human thymocytes. J Immunol (1987) $139: 490-3$.

43. Viselli SM, Reese KR, Fan J, Kovacs WJ, Olsen NJ. Androgens alter B cell development in normal male mice. Cell Immunol (1997) 182:99-104. doi:10.1006/cimm.1997.1227

44. Lai KP, Lai JJ, Chang P, Altuwaijri S, Hsu JW, Chuang KH, et al. Targeting thymic epithelia AR enhances T-cell reconstitution and bone marrow transplant grafting efficacy. Mol Endocrinol (2013) 27:25-37. doi:10.1210/ me.012-1244

45. Chuang KH, Altuwaijri S, Li G, Lai JJ, Chu CY, Lai KP, et al. Neutropenia with impaired host defense against microbial infection in mice lacking androgen receptor. J Exp Med (2009) 206:1181-99. doi:10.1084/jem.20082521

46. McDonnell ND, Livingston RB. Severe reversible neutropenia following treatment of prostate cancer with flutamide. J Urol (1994) 151:1353-4. doi:10.1016/S0022-5347(17)35251-5

47. Ibanez L, Jaramillo AM, Ferrer A, de ZF. High neutrophil count in girls and women with hyperinsulinaemic hyperandrogenism: normalization with metformin and flutamide overcomes the aggravation by oral contraception. Hum Reprod (2005) 20:2457-62. doi:10.1093/humrep/dei072

48. Trigunaite A, Khan A, Der E, Song A, Varikuti S, Jorgensen TN. Gr1 CD11b cells suppress B cell differentiation and lupus-like disease in lupus-prone male mice. Arthritis Rheum (2013) 65:2392-402. doi:10.1002/art.38048

49. Bird AK, Chang M, Barnard J, Goldman BI, Meednu N, Rangel-Moreno J, et al. Neutrophils slow disease progression in murine lupus via modulation of autoreactive germinal centers. J Immunol (2017) 199:458-66. doi:10.4049/ jimmunol.1700354

50. Inamdar Doddamani LS, Jayamma Y. Acceleration of neutrophil precursors' maturation and immunostimulation of $\mathrm{CD} 3+, \mathrm{CD} 4+$ lymphocytes by stanozolol in mice. J Steroid Biochem Mol Biol (2012) 129:172-8. doi:10.1016/j. jsbmb.2011.11.008

51. Marin DP, Bolin AP, dos Santos RC, Curi R, Otton R. Testosterone suppresses oxidative stress in human neutrophils. Cell Biochem Funct (2010) 28:394-402. doi:10.1002/cbf.1669

52. Malkin CJ, Pugh PJ, Jones RD, Kapoor D, Channer KS, Jones TH. The effect of testosterone replacement on endogenous inflammatory cytokines and lipid 
profiles in hypogonadal men. J Clin Endocrinol Metab (2004) 89:3313-8. doi:10.1210/jc.2003-031069

53. Hughes TK, Fulep E, Juelich T, Smith EM, Stanton GJ. Modulation of immune responses by anabolic androgenic steroids. Int J Immunopharmacol (1995) 17:857-63. doi:10.1016/0192-0561(95)00078-X

54. Arazi H, Mohammadjafari H, Asadi A. Use of anabolic androgenic steroids produces greater oxidative stress responses to resistance exercise in strength-trained men. Toxicol Rep (2017) 4:282-6. doi:10.1016/j.toxrep.2017. 05.005

55. Corrales JJ, Almeida M, Miralles JM, Orfao A. Persistence of androgenic effects on the production of proinflammatory cytokines by circulating antigen-presenting cells after withdrawal of testosterone treatment in aging type 2 diabetic men with partial androgen deficiency. Fertil Steril (2009) 92: 311-9. doi:10.1016/j.fertnstert.2008.05.040

56. Ashcroft GS, Mills SJ. Androgen receptor-mediated inhibition of cutaneous wound healing. J Clin Invest (2002) 110:615-24. doi:10.1172/JCI15704

57. Goncalves RV, Novaes RD, Sarandy MM, Damasceno EM, da Matta SL, de Gouveia NM, et al. 5alpha-dihydrotestosterone enhances wound healing in diabetic rats. Life Sci (2016) 152:67-75. doi:10.1016/j.lfs.2016.03.019

58. Rettew JA, Huet-Hudson YM, Marriott I. Testosterone reduces macrophage expression in the mouse of toll-like receptor 4, a trigger for inflammation and innate immunity. Biol Reprod (2008) 78:432-7. doi:10.1095/ biolreprod.107.063545

59. Angele MK, Schwacha MG, Ayala A, Chaudry IH. Effect of gender and sex hormones on immune responses following shock. Shock (2000) 14: 81-90. doi:10.1097/00024382-200014020-00001

60. Newsome CT, Flores E, Ayala A, Gregory S, Reichner JS. Improved antimicrobial host defense in mice following poly-(1,6)-beta-D-glucopyranosyl$(1,3)$-beta-D-glucopyranose glucan treatment by a gender-dependent immune mechanism. Clin Vaccine Immunol (2011) 18:2043-9. doi:10.1128/ CVI.05202-11

61. Lima AP, Lunardi LO, Rosa E Silva AA. Effects of castration and testosterone replacement on peritoneal histamine concentration and lung histamine concentration in pubertal male rats. JEndocrinol (2000) 167:71-5. doi:10.1677/joe.0.1670071

62. Russi AE, Ebel ME, Yang Y, Brown MA. Male-specific IL-33 expression regulates sex-dimorphic EAE susceptibility. Proc Natl Acad Sci U S A (2018) 115:E1520-9. doi:10.1073/pnas.1710401115

63. Kornizky Y, Topilsky M, Fireman E, Kivity S, Kivity S. Specific IgE antibodies to aeroallergens and food among Israelis. Ann Allergy Asthma Immunol (1999) 83:149-52. doi:10.1016/S1081-1206(10)62627-0

64. Paula Couto TA, Falsarella N, Mattos CC, Mattos LC. Total IgE plasma levels vary according to gender and age in Brazilian patients with allergic rhinitis. Clinics (Sao Paulo) (2014) 69:740-4. doi:10.6061/clinics/2014(11)06

65. Nakanishi H, Horii Y, Fujita K. Effect of testosterone on the eosinophil response of C57BL/6 mice to infection with Brugia pahangi. Immunopharmacology (1992) 23:75-9. doi:10.1016/0162-3109(92)90030-G

66. Yamatomo T, Okano M, Ono T, Nakayama E, Yoshino T, Satoskar AR, et al. Sex-related differences in the initiation of allergic rhinitis in mice. Allergy (2001) 56:525-31. doi:10.1034/j.1398-9995.2001.056006525.x

67. Hamano N, Terada N, Maesako K, Numata T, Konno A. Effect of sex hormones on eosinophilic inflammation in nasal mucosa. Allergy Asthma Proc (1998) 19:263-9. doi:10.2500/108854198778557773

68. Liou CJ, Huang WC. Dehydroepiandrosterone suppresses eosinophil infiltration and airway hyperresponsiveness via modulation of chemokines and Th2 cytokines in ovalbumin-sensitized mice. JClin Immunol (2011) 31:656-65. doi:10.1007/s10875-011-9529-3

69. Kamis AB, Ibrahim JB. Effects of testosterone on blood leukocytes in plasmodium berghei-infected mice. Parasitol Res (1989) 75:611-3. doi:10.1007/ BF00930957

70. Lin AA, Wojciechowski SE, Hildeman DA. Androgens suppress antigenspecific $\mathrm{T}$ cell responses and IFN-gamma production during intracranial LCMV infection. J Neuroimmunol (2010) 226:8-19. doi:10.1016/j.jneuroim. 2010.05.026

71. Koh YT, Gray A, Higgins SA, Hubby B, Kast WM. Androgen ablation augments prostate cancer vaccine immunogenicity only when applied after immunization. Prostate (2009) 69:571-84. doi:10.1002/pros.20906

72. Corrales JJ, Almeida M, Cordero M, Martin-Martin L, Mendez C, Miralles JM, et al. Enhanced immunological response by dendritic cells in male hypogonadism. Eur J Clin Invest (2012) 42:1205-12. doi:10.1111/ j.1365-2362.2012.02712.x

73. Hepworth MR, Hardman MJ, Grencis RK. The role of sex hormones in the development of Th2 immunity in a gender-biased model of Trichuris muris infection. Eur J Immunol (2010) 40:406-16. doi:10.1002/eji.200939589

74. Klein SL, Flanagan KL. Sex differences in immune responses. Nat Rev Immunol (2016) 16:626-38. doi:10.1038/nri.2016.90

75. Cutolo M, Balleari E, Accardo S, Samanta E, Cimmino MA, Giusti M, et al. Preliminary results of serum androgen level testing in men with rheumatoid arthritis. Arthritis Rheum (1984) 27:958-9. doi:10.1002/art.1780270821

76. Spector TD, Perry LA, Tubb G, Silman AJ, Huskisson EC. Low free testosterone levels in rheumatoid arthritis. Ann Rheum Dis (1988) 47:65-8. doi:10.1136/ard.47.1.65

77. Olsen NJ, Kovacs WJ. Effects of androgens on T and B lymphocyte development. Immunol Res (2001) 23:281-8. doi:10.1385/IR:23:2-3:281

78. Olsen NJ, Benko AL, Kovacs WJ. Variation in the androgen receptor gene exon 1 CAG repeat correlates with manifestations of autoimmunity in women with lupus. Endocr Connect (2014) 3:99-109. doi:10.1530/EC-14-0039

79. Robeva R, Tanev D, Andonova S, Kirilov G, Savov A, Stoycheva M, et al. Androgen receptor (CAG)n polymorphism and androgen levels in women with systemic lupus erythematosus and healthy controls. Rheumatol Int (2013) 33:2031-8. doi:10.1007/s00296-013-2687-2

80. Furman D, Hejblum BP, Simon N, Jojic V, Dekker CL, Thiebaut R, et al. Systems analysis of sex differences reveals an immunosuppressive role for testosterone in the response to influenza vaccination. Proc Natl Acad Sci U S A (2014) 111:869-74. doi:10.1073/pnas.1321060111

81. Lundell AC, Nordstrom I, Andersson K, Strombeck A, Ohlsson C, Tivesten A, et al. Dihydrotestosterone levels at birth associate positively with higher proportions of circulating immature/naive CD5(+) B cells in boys. Sci Rep (2017) 7:15503. doi:10.1038/s41598-017-15836-1

82. Lundell AC, Hesselmar B, Nordstrom I, Adlerberth I, Wold AE, Rudin A. Higher B-cell activating factor levels at birth are positively associated with maternal dairy farm exposure and negatively related to allergy development. J Allergy Clin Immunol (2015) 136:1074-82. doi:10.1016/j.jaci.2015.03.022

83. Smithson G, Beamer WG, Shultz KL, Christianson SW, Shultz LD, Kincade PW. Increased B lymphopoiesis in genetically sex steroid-deficient hypogonadal (hpg) mice. J Exp Med (1994) 180:717-20. doi:10.1084/jem. 180.2.717

84. Ellis TM, Moser MT, Le PT, Flanigan RC, Kwon ED. Alterations in peripheral B cells and B cell progenitors following androgen ablation in mice. Int Immunol (2001) 13:553-8. doi:10.1093/intimm/13.4.553

85. Altuwaijri S, Chuang KH, Lai KP, Lai JJ, Lin HY, Young FM, et al. Susceptibility to autoimmunity and B cell resistance to apoptosis in mice lacking androgen receptor in B cells. Mol Endocrinol (2009) 23:444-53. doi:10.1210/me.2008-0106

86. Wilhelmson AS, Stubelius A, Borjesson AE, Wu J, Stern A, Malin S, et al. Androgens regulate bone marrow $\mathrm{B}$ lymphopoiesis in male mice by targeting osteoblast-lineage cells. Endocrinology (2015) 156:1228-36. doi:10.1210/en. 2014-1822

87. Tang J, Nuccie BL, Ritterman I, Liesveld JL, Abboud CN, Ryan DH. TGFbeta down-regulates stromal IL-7 secretion and inhibits proliferation of human B cell precursors. J Immunol (1997) 159:117-25.

88. Olsen NJ, Viselli SM, Fan J, Kovacs WJ. Androgens accelerate thymocyte apoptosis. Endocrinology (1998) 139:748-52. doi:10.1210/endo.139.2.5729

89. Olsen NJ, Kovacs WJ. Increased thymic size and thymocyte interleukin 2 production in androgen-resistant mice. Scand J Immunol (1989) 29:733-8. doi:10.1111/j.1365-3083.1989.tb01178.x

90. Olsen NJ, Watson MB, Henderson GS, Kovacs WJ. Androgen deprivation induces phenotypic and functional changes in the thymus of adult male mice. Endocrinology (1991) 129:2471-6. doi:10.1210/endo-129-5-2471

91. Greenstein BD, Fitzpatrick FT, Adcock IM, Kendall MD, Wheeler MJ. Reappearance of the thymus in old rats after orchidectomy: inhibition of regeneration by testosterone. J Endocrinol (1986) 110:417-22. doi:10.1677/ joe. 0.1100417

92. Roden AC, Moser MT, Tri SD, Mercader M, Kuntz SM, Dong H, et al. Augmentation of $\mathrm{T}$ cell levels and responses induced by androgen deprivation. J Immunol (2004) 173:6098-108. doi:10.4049/jimmunol.173.10.6098

93. Sutherland JS, Goldberg GL, Hammett MV, Uldrich AP, Berzins SP, Heng TS, et al. Activation of thymic regeneration in mice and humans 
following androgen blockade. J Immunol (2005) 175:2741-53. doi:10.4049/ jimmunol.175.4.2741

94. Song W, Soni V, Soni S, Khera M. Testosterone inhibits the growth of prostate cancer xenografts in nude mice. BMC Cancer (2017) 17:635. doi:10.1186/ s12885-017-3569-x

95. Olsen NJ, Viselli SM, Shults K, Stelzer G, Kovacs WJ. Induction of immature thymocyte proliferation after castration of normal male mice. Endocrinology (1994) 134:107-13. doi:10.1210/endo.134.1.8275924

96. Aboudkhil S, Bureau JP, Garrelly L, Vago P. Effects of castration, depotestosterone and cyproterone acetate on lymphocyte $T$ subsets in mouse thymus and spleen. Scand J Immunol (1991) 34:647-53. doi:10.1111/j.13653083.1991.tb01588.x

97. Zhu ML, Bakhru P, Conley B, Nelson JS, Free M, Martin A, et al. Sex bias in CNS autoimmune disease mediated by androgen control of autoimmune regulator. Nat Commun (2016) 7:11350. doi:10.1038/ncomms11350

98. Olsen NJ, Zhou P, Ong H, Kovacs WJ. Testosterone induces expression of transforming growth factor-beta 1 in the murine thymus. J Steroid Biochem Mol Biol (1993) 45:327-32. doi:10.1016/0960-0760(93)90001-D

99. Viselli SM, Stanziale S, Shults K, Kovacs WJ, Olsen NJ. Castration alters peripheral immune function in normal male mice. Immunology (1995) 84: $337-42$.

100. Jia T, Anandhan A, Massilamany C, Rajasekaran RA, Franco R, Reddy J. Association of autophagy in the cell death mediated by dihydrotestosterone in autoreactive $\mathrm{T}$ cells independent of antigenic stimulation. J Neuroimmune Pharmacol (2015) 10:620-34. doi:10.1007/s11481-015-9633-x

101. Weinstein Y, Ran S, Segal S. Sex-associated differences in the regulation of immune responses controlled by the MHC of the mouse. J Immunol (1984) 132:656-61.

102. Olsen NJ, Kovacs WJ. Gonadal steroids and immunity. Endocr Rev (1996) 17:369-84. doi:10.1210/edrv-17-4-369

103. Massa MG, David C, Jorg S, Berg J, Gisevius B, Hirschberg S, et al. Testosterone differentially affects $\mathrm{T}$ cells and neurons in murine and human models of neuroinflammation and neurodegeneration. Am J Pathol (2017) 187:1613-22. doi:10.1016/j.ajpath.2017.03.006

104. Fijak M, Schneider E, Klug J, Bhushan S, Hackstein H, Schuler G, et al. Testosterone replacement effectively inhibits the development of experimental autoimmune orchitis in rats: evidence for a direct role of testosterone on regulatory T cell expansion. J Immunol (2011) 186:5162-72. doi:10.4049/ jimmunol.1001958

105. Kissick HT, Sanda MG, Dunn LK, Pellegrini KL, On ST, Noel JK, et al. Androgens alter T-cell immunity by inhibiting T-helper 1 differentiation. Proc Natl Acad Sci U S A (2014) 111:9887-92. doi:10.1073/pnas. 1402468111

106. Wilcoxen SC, Kirkman E, Dowdell KC, Stohlman SA. Gender-dependent IL-12 secretion by APC is regulated by IL-10. J Immunol (2000) 164:6237-43. doi:10.4049/jimmunol.164.12.6237

107. Bao M, Yang Y, Jun HS, Yoon JW. Molecular mechanisms for gender differences in susceptibility to $\mathrm{T}$ cell-mediated autoimmune diabetes in nonobese diabetic mice. JImmunol (2002) 168:5369-75. doi:10.4049/ jimmunol.168.10.5369

108. Zhang MA, Ahn JJ, Zhao FL, Selvanantham T, Mallevaey T, Stock N, et al. Antagonizing peroxisome proliferator-activated receptor alpha activity selectively enhances Th1 immunity in male mice. J Immunol (2015) 195: 5189-202. doi:10.4049/jimmunol.1500449

109. Dunn SE, Ousman SS, Sobel RA, Zuniga L, Baranzini SE, Youssef S, et al. Peroxisome proliferator-activated receptor (PPAR)alpha expression in $\mathrm{T}$ cells mediates gender differences in development of $\mathrm{T}$ cell-mediated autoimmunity. J Exp Med (2007) 204:321-30. doi:10.1084/jem.20061839

110. Rutkowski K, Sowa P, Rutkowska-Talipska J, Kuryliszyn-Moskal A, Rutkowski R. Dehydroepiandrosterone (DHEA): hypes and hopes. Drugs (2014) 74:1195-207. doi:10.1007/s40265-014-0259-8

111. Walecki M, Eisel F, Klug J, Baal N, Paradowska-Dogan A, Wahle E, et al. Androgen receptor modulates Foxp3 expression in CD4+CD25+Foxp3+ regulatory T-cells. Mol Biol Cell (2015) 26:2845-57. doi:10.1091/mbc. E14-08-1323

112. Lieberman SM, Kreiger PA, Koretzky GA. Reversible lacrimal glandprotective regulatory T-cell dysfunction underlies male-specific autoimmune dacryoadenitis in the non-obese diabetic mouse model of Sjogren syndrome. Immunology (2015) 145:232-41. doi:10.1111/imm.12439
113. Whitacre CC. Sex differences in autoimmune disease. Nat Immunol (2001) 2:777-80. doi:10.1038/ni0901-777

114. Seminog OO, Seminog AB, Yeates D, Goldacre MJ. Associations between Klinefelter's syndrome and autoimmune diseases: English national record linkage studies. Autoimmunity (2015) 48:125-8. doi:10.3109/08916934. 2014.968918

115. Foster SC, Daniels C, Bourdette DN, Bebo BF Jr. Dysregulation of the hypothalamic-pituitary-gonadal axis in experimental autoimmune encephalomyelitis and multiple sclerosis. JNeuroimmunol (2003) 140:78-87. doi:10.1016/S0165-5728(03)00177-2

116. Baillargeon J, Al SS, Raji MA, Urban RJ, Sharma G, Sheffield-Moore M, et al. Hypogonadism and the risk of rheumatic autoimmune disease. Clin Rheumatol (2016) 35:2983-7. doi:10.1007/s10067-016-3330-x

117. McInnes IB, Schett G. The pathogenesis of rheumatoid arthritis. N Engl J Med (2011) 365:2205-19. doi:10.1056/NEJMra 1004965

118. Kuiper S, van Gestel AM, Swinkels HL, de Boo TM, Da Silva JA, van Riel PL. Influence of sex, age, and menopausal state on the course of early rheumatoid arthritis. J Rheumatol (2001) 28:1809-16.

119. Tengstrand B, Ahlmen M, Hafstrom I. The influence of sex on rheumatoid arthritis: a prospective study of onset and outcome after 2 years. J Rheumatol (2004) 31:214-22.

120. Forslind K, Hafstrom I, Ahlmen M, Svensson B. Sex: a major predictor of remission in early rheumatoid arthritis? Ann Rheum Dis (2007) 66:46-52. doi:10.1136/ard.2006.056937

121. Iikuni N, Sato E, Hoshi M, Inoue E, Taniguchi A, Hara M, et al. The influence of sex on patients with rheumatoid arthritis in a large observational cohort. J Rheumatol (2009) 36:508-11. doi:10.3899/jrheum.080724

122. Weyand CM, Schmidt D, Wagner U, Goronzy JJ. The influence of sex on the phenotype of rheumatoid arthritis. Arthritis Rheum (1998) 41:817-22. doi:10.1002/1529-0131(199805)41:5<817:AID-ART7>3.0.CO;2-S

123. Islander $\mathrm{U}$, Jochems $\mathrm{C}$, Lagerquist $\mathrm{MK}$, Forsblad-d'Elia $\mathrm{H}$, Carlsten $\mathrm{H}$. Estrogens in rheumatoid arthritis; the immune system and bone. Mol Cell Endocrinol (2011) 335:14-29. doi:10.1016/j.mce.2010.05.018

124. Davidson JM, Chen JJ, Crapo L, Gray GD, Greenleaf WJ, Catania JA. Hormonal changes and sexual function in aging men. JClin Endocrinol Metab (1983) 57:71-7. doi:10.1210/jcem-57-1-71

125. Gordon D, Beastall GH, Thomson JA, Sturrock RD. Androgenic status and sexual function in males with rheumatoid arthritis and ankylosing spondylitis. Q J Med (1986) 60:671-9.

126. Cutolo M, Balleari E, Giusti M, Monachesi M, Accardo S. Sex hormone status of male patients with rheumatoid arthritis: evidence of low serum concentrations of testosterone at baseline and after human chorionic gonadotropin stimulation. Arthritis Rheum (1988) 31:1314-7. doi:10.1002/ art.1780311015

127. Heikkila R, Aho K, Heliovaara M, Knekt P, Reunanen A, Aromaa A, et al. Serum androgen-anabolic hormones and the risk of rheumatoid arthritis. Ann Rheum Dis (1998) 57:281-5. doi:10.1136/ard.57.5.281

128. Khalkhali-Ellis Z, Moore TL, Hendrix MJ. Reduced levels of testosterone and dehydroepiandrosterone sulphate in the serum and synovial fluid of juvenile rheumatoid arthritis patients correlates with disease severity. Clin Exp Rheumatol (1998) 16:753-6.

129. Kanik KS, Chrousos GP, Schumacher HR, Crane ML, Yarboro CH, Wilder RL. Adrenocorticotropin, glucocorticoid, and androgen secretion in patients with new onset synovitis/rheumatoid arthritis: relations with indices of inflammation. J Clin Endocrinol Metab (2000) 85:1461-6. doi:10.1210/jcem. 85.4.6534

130. Tengstrand B, Carlstrom K, Hafstrom I. Gonadal hormones in men with rheumatoid arthritis - from onset through 2 years. JRheumatol (2009) 36:887-92. doi:10.3899/jrheum.080558

131. Kawasaki T, Ushiyama T, Ueyama H, Inoue K, Mori K, Ohkubo I, et al. Polymorphic CAG repeats of the androgen receptor gene and rheumatoid arthritis. Ann Rheum Dis (1999) 58:500-2. doi:10.1136/ard.58.8.500

132. Lo SF, Huang CM, Tsai CH, Chen WC, Lai CC, Tsai Y, et al. Androgen receptor gene polymorphism and rheumatoid arthritis in Taiwan. Clin Exp Rheumatol (2006) 24:209-10.

133. Karlson EW, Chibnik LB, McGrath M, Chang SC, Keenan BT, Costenbader $\mathrm{KH}$, et al. A prospective study of androgen levels, hormonerelated genes and risk of rheumatoid arthritis. Arthritis Res Ther (2009) 11:R97. doi:10.1186/ar2742 
134. Pope JE, Joneja M, Hong P. Anti-androgen treatment of prostatic carcinoma may be a risk factor for development of rheumatoid arthritis. J Rheumatol (2002) 29:2459-62.

135. Pikwer M, Giwercman A, Bergstrom U, Nilsson JA, Jacobsson LT, Turesson C. Association between testosterone levels and risk of future rheumatoid arthritis in men: a population-based case-control study. Ann Rheum Dis (2014) 73:573-9. doi:10.1136/annrheumdis-2012-202781

136. Imrich R, Rovensky J, Malis F, Zlnay M, Killinger Z, Kvetnansky R, et al. Low levels of dehydroepiandrosterone sulphate in plasma, and reduced sympathoadrenal response to hypoglycaemia in premenopausal women with rheumatoid arthritis. Ann Rheum Dis (2005) 64:202-6. doi:10.1136/ ard.2003.019844

137. Gordon D, Beastall GH, Thomson JA, Sturrock RD. Prolonged hypogonadism in male patients with rheumatoid arthritis during flares in disease activity. Br J Rheumatol (1988) 27:440-4. doi:10.1093/rheumatology/27.6.440

138. Masi AT, Chatterton RT, Aldag JC. Perturbations of hypothalamicpituitary-gonadal axis and adrenal androgen functions in rheumatoid arthritis: an odyssey of hormonal relationships to the disease. Ann NY Acad Sci (1999) 876:53-62. doi:10.1111/j.1749-6632.1999.tb07622.x

139. Cutolo M, Foppiani L, Prete C, Ballarino P, Sulli A, Villaggio B, et al. Hypothalamic-pituitary-adrenocortical axis function in premenopausal women with rheumatoid arthritis not treated with glucocorticoids. J Rheumatol (1999) 26:282-8.

140. Deighton CM, Watson MJ, Walker DJ. Sex hormones in postmenopausal HLA-identical rheumatoid arthritis discordant sibling pairs. J Rheumatol (1992) 19:1663-7.

141. Stark K, Straub RH, Rovensky J, Blazickova S, Eiselt G, Schmidt M. CYB5A polymorphism increases androgens and reduces risk of rheumatoid arthritis in women. Arthritis Res Ther (2015) 17:56. doi:10.1186/s13075015-0574-9

142. Yu SF, Cheng TT, Hsu YH, Lai HM, Chen YC, Chiu CK, et al. Association of tri-nucleotide (CAG and GGC) repeat polymorphism of androgen receptor gene in Taiwanese women with refractory or remission rheumatoid arthritis. Clin Rheumatol (2007) 26:2051. doi:10.1007/s10067-007-0616-Z

143. Cutolo M, Balleari E, Giusti M, Monachesi M, Accardo S. Sex hormone status in women suffering from rheumatoid arthritis. J Rheumatol (1986) 13:1019-23.

144. Dziedziejko V, Kurzawski M, Safranow K, Ossowski A, Piatek J, Parafiniuk M, et al. CAG repeat polymorphism in the androgen receptor gene in women with rheumatoid arthritis. JRheumatol (2012) 39:10-7. doi:10.3899/ jrheum.110894

145. Margolis HM, Caplan PS. The effect of some steroids (testosterone propionate, desoxycorticosterone acetate and ascorbic acid, and 21-acetoxy delta-5-pregnenolone, artisone acetate, Wyeth) in rheumatoid arthritis. Ann Intern Med (1951) 34:61-71. doi:10.7326/0003-4819-34-1-61

146. Cutolo M, Balleari E, Giusti M, Intra E, Accardo S. Androgen replacement therapy in male patients with rheumatoid arthritis. Arthritis Rheum (1991) 34:1-5. doi:10.1002/art.1780340102

147. Booji A, Biewenga-Booji CM, Huber-Bruning O, Cornelis C, Jacobs JW, Bijlsma JW. Androgens as adjuvant treatment in postmenopausal female patients with rheumatoid arthritis. Ann Rheum Dis (1996) 55:811-5. doi:10.1136/ard.55.11.811

148. Hall GM, Larbre JP, Spector TD, Perry LA, Da Silva JA. A randomized trial of testosterone therapy in males with rheumatoid arthritis. Br J Rheumatol (1996) 35:568-73. doi:10.1093/rheumatology/35.6.568

149. Ganesan K, Balachandran C, Manohar BM, Puvanakrishnan R. Comparative studies on the interplay of testosterone, estrogen and progesterone in collagen induced arthritis in rats. Bone (2008) 43:758-65. doi:10.1016/j. bone.2008.05.025

150. Homo-Delarche F, Fitzpatrick F, Christeff N, Nunez EA, Bach JF, Dardenne M. Sex steroids, glucocorticoids, stress and autoimmunity. J Steroid Biochem Mol Biol (1991) 40:619-37. doi:10.1016/0960-0760(91) 90285-D

151. Da Silva JA, Larbre JP, Seed MP, Cutolo M, Villaggio B, Scott DL, et al. Sex differences in inflammation induced cartilage damage in rodents. The influence of sex steroids. J Rheumatol (1994) 21:330-7.

152. Keith RC, Sokolove J, Edelman BL, Lahey L, Redente EF, Holers VM, et al. Testosterone is protective in the sexually dimorphic development of arthritis and lung disease in SKG mice. Arthritis Rheum (2013) 65:1487-93. doi: $10.1002 /$ art.37943

153. Bruot BC, Clemens JW. Effect of adjuvant-induced arthritis on serum luteinizing hormone and testosterone concentrations in the male rat. Life Sci (1987) 41:1559-65. doi:10.1016/0024-3205(87)90722-3

154. Castagnetta LA, Carruba G, Granata OM, Stefano R, Miele M, Schmidt M, et al. Increased estrogen formation and estrogen to androgen ratio in the synovial fluid of patients with rheumatoid arthritis. J Rheumatol (2003) 30: 2597-605.

155. Cutolo M, Accardo S, Villaggio B, Barone A, Sulli A, Balleari E, et al. Androgen metabolism and inhibition of interleukin-1 synthesis in primary cultured human synovial macrophages. Mediators Inflamm (1995) 4:138-43. doi:10.1155/S096293519500024X

156. Keller ET, Chang C, Ershler WB. Inhibition of NFkappaB activity through maintenance of IkappaBalpha levels contributes to dihydrotestosteronemediated repression of the interleukin-6 promoter. JBiol Chem (1996) 271:26267-75. doi:10.1074/jbc.271.42.26267

157. Capellino S, Straub RH, Cutolo M. Aromatase and regulation of the estrogen-to-androgen ratio in synovial tissue inflammation: common pathway in both sexes. Ann N Y Acad Sci (2014) 1317:24-31. doi:10.1111/nyas.12398

158. Li ZG, Danis VA, Brooks PM. Effect of gonadal steroids on the production of IL-1 and IL-6 by blood mononuclear cells in vitro. Clin Exp Rheumatol (1993) 11:157-62.

159. Dunn SE, Lee H, Pavri FR, Zhang MA. Sex-based differences in multiple sclerosis (part I): biology of disease incidence. Curr Top Behav Neurosci (2015) 26:29-56. doi:10.1007/7854_2015_371

160. Kalincik T, Vivek V, Jokubaitis V, Lechner-Scott J, Trojano M, Izquierdo G, et al. Sex as a determinant of relapse incidence and progressive course of multiple sclerosis. Brain (2013) 136:3609-17. doi:10.1093/brain/awt281

161. Tremlett H, Zhao Y, Joseph J, Devonshire V. Relapses in multiple sclerosis are age- and time-dependent. J Neurol Neurosurg Psychiatry (2008) 79:1368-74. doi:10.1136/jnnp.2008.145805

162. Held U, Heigenhauser L, Shang C, Kappos L, Polman C. Predictors of relapse rate in MS clinical trials. Neurology (2005) 65:1769-73. doi:10.1212/01. wnl.0000187122.71735.1f

163. Weatherby SJ, Mann CL, Davies MB, Fryer AA, Haq N, Strange RC, et al. A pilot study of the relationship between gadolinium-enhancing lesions, gender effect and polymorphisms of antioxidant enzymes in multiple sclerosis. J Neurol (2000) 247:467-70. doi:10.1007/s004150070179

164. Pozzilli C, Tomassini V, Marinelli F, Paolillo A, Gasperini C, Bastianello S. 'Gender gap' in multiple sclerosis: magnetic resonance imaging evidence. Eur J Neurol (2003) 10:95-7. doi:10.1046/j.1468-1331.2003.00519.x

165. Tomassini V, Onesti E, Mainero C, Giugni E, Paolillo A, Salvetti M, et al. Sex hormones modulate brain damage in multiple sclerosis: MRI evidence. J Neurol Neurosurg Psychiatry (2005) 76:272-5. doi:10.1136/jnnp.2003. 033324

166. Foroughipour A, Norbakhsh V, Najafabadi SH, Meamar R. Evaluating sex hormone levels in reproductive age women with multiple sclerosis and their relationship with disease severity. J Res Med Sci (2012) 17:882-5.

167. Bove R, Musallam A, Healy BC, Raghavan K, Glanz BI, Bakshi R, et al. Low testosterone is associated with disability in men with multiple sclerosis. Mult Scler (2014) 20:1584-92. doi:10.1177/1352458514527864

168. Tellez N, Comabella M, Julia E, Rio J, Tintore M, Brieva L, et al. Fatigue in progressive multiple sclerosis is associated with low levels of dehydroepiandrosterone. Mult Scler (2006) 12:487-94. doi:10.1191/135248505ms1322oa

169. Sicotte NL, Giesser BS, Tandon V, Klutch R, Steiner B, Drain AE, et al. Testosterone treatment in multiple sclerosis: a pilot study. Arch Neurol (2007) 64:683-8. doi:10.1001/archneur.64.5.683

170. Kurth F, Luders E, Sicotte NL, Gaser C, Giesser BS, Swerdloff RS, et al. Neuroprotective effects of testosterone treatment in men with multiple sclerosis. Neuroimage Clin (2014) 4:454-60. doi:10.1016/j.nicl.2014.03.001

171. Cannella B, Raine CS. The adhesion molecule and cytokine profile of multiple sclerosis lesions. Ann Neurol (1995) 37:424-35. doi:10.1002/ana. 410370404

172. Balashov KE, Rottman JB, Weiner HL, Hancock WW. CCR5(+) and CXCR3(+) T cells are increased in multiple sclerosis and their ligands MIP1alpha and IP-10 are expressed in demyelinating brain lesions. Proc Natl Acad Sci U S A (1999) 96:6873-8. doi:10.1073/pnas.96.12.6873 
173. Kebir H, Ifergan I, Alvarez JI, Bernard M, Poirier J, Arbour N, et al. Preferential recruitment of interferon-gamma-expressing TH17 cells in multiple sclerosis. Ann Neurol (2009) 66:390-402. doi:10.1002/ana.21748

174. Tzartos JS, Friese MA, Craner MJ, Palace J, Newcombe J, Esiri MM, et al. Interleukin-17 production in central nervous system-infiltrating $\mathrm{T}$ cells and glial cells is associated with active disease in multiple sclerosis. Am J Pathol (2008) 172:146-55. doi:10.2353/ajpath.2008.070690

175. Lock C, Hermans G, Pedotti R, Brendolan A, Schadt E, Garren H, et al. Gene-microarray analysis of multiple sclerosis lesions yields new targets validated in autoimmune encephalomyelitis. Nat Med (2002) 8:500-8. doi:10.1038/nm0502-500

176. Krumbholz M, Derfuss T, Hohlfeld R, Meinl E. B cells and antibodies in multiple sclerosis pathogenesis and therapy. Nat Rev Neurol (2012) 8:613-23. doi:10.1038/nrneurol.2012.203

177. Havrdova E, Belova A, Goloborodko A, Tisserant A, Wright A, Wallstroem E, et al. Activity of secukinumab, an anti-IL-17A antibody, on brain lesions in RRMS: results from a randomized, proof-of-concept study. J Neurol (2016) 263:1287-95. doi:10.1007/s00415-016-8128-x

178. Hauser SL, Waubant E, Arnold DL, Vollmer T, Antel J, Fox RJ, et al. B-cell depletion with rituximab in relapsing-remitting multiple sclerosis. $N$ Engl J Med (2008) 358:676-88. doi:10.1056/NEJMoa0706383

179. Segal BM, Constantinescu CS, Raychaudhuri A, Kim L, Fidelus-Gort R, Kasper LH. Repeated subcutaneous injections of IL12/23 p40 neutralising antibody, ustekinumab, in patients with relapsing-remitting multiple sclerosis: a phase II, double-blind, placebo-controlled, randomised, doseranging study. Lancet Neurol (2008) 7:796-804. doi:10.1016/S1474-4422 (08)70173-X

180. Dalal M, Kim S, Voskuhl RR. Testosterone therapy ameliorates experimental autoimmune encephalomyelitis and induces a T helper 2 bias in the autoantigen-specific T lymphocyte response. J Immunol (1997) 159:3-6.

181. Palaszynski KM, Loo KK, Ashouri JF, Liu HB, Voskuhl RR. Androgens are protective in experimental autoimmune encephalomyelitis: implications for multiple sclerosis. J Neuroimmunol (2004) 146:144-52. doi:10.1016/j. jneuroim.2003.11.004

182. Ziehn MO, Avedisian AA, Dervin SM, Umeda EA, O’Dell TJ, Voskuhl RR. Therapeutic testosterone administration preserves excitatory synaptic transmission in the hippocampus during autoimmune demyelinating disease. J Neurosci (2012) 32:12312-24. doi:10.1523/JNEUROSCI.2796-12.2012

183. Giatti S, Rigolio R, Romano S, Mitro N, Viviani B, Cavaletti G, et al. Dihydrotestosterone as a protective agent in chronic experimental autoimmune encephalomyelitis. Neuroendocrinology (2015) 101:296-308. doi:10.1159/ 000381064

184. Cua DJ, Hinton DR, Stohlman SA. Self-antigen-induced Th2 responses in experimental allergic encephalomyelitis (EAE)-resistant mice. Th2-mediated suppression of autoimmune disease. J Immunol (1995) 155:4052-9.

185. Bebo BF Jr, Zelinka-Vincent E, Adamus G, Amundson D, Vandenbark AA, Offner H. Gonadal hormones influence the immune response to PLP 139-151 and the clinical course of relapsing experimental autoimmune encephalomyelitis. J Neuroimmunol (1998) 84:122-30. doi:10.1016/S0165-5728(97) 00214-2

186. Pelfrey CM, Cotleur AC, Lee JC, Rudick RA. Sex differences in cytokine responses to myelin peptides in multiple sclerosis. J Neuroimmunol (2002) 130:211-23. doi:10.1016/S0165-5728(02)00224-2

187. Moldovan IR, Cotleur AC, Zamor N, Butler RS, Pelfrey CM. Multiple sclerosis patients show sexual dimorphism in cytokine responses to myelin antigens. J Neuroimmunol (2008) 193:161-9. doi:10.1016/j.jneuroim.2007. 10.010

188. Bebo BF Jr, Schuster JC, Vandenbark AA, Offner H. Androgens alter the cytokine profile and reduce encephalitogenicity of myelin-reactive $\mathrm{T}$ cells. J Immunol (1999) 162:35-40.

189. Brahmachari S, Pahan K. Gender-specific expression of betal integrin of VLA-4 in myelin basic protein-primed T cells: implications for gender bias in multiple sclerosis. J Immunol (2010) 184:6103-13. doi:10.4049/ jimmunol.0804356

190. Kotzin BL. Systemic lupus erythematosus. Cell (1996) 85:303-6. doi:10.1016/ S0092-8674(00)81108-3

191. Mills JA. Systemic lupus erythematosus. N Engl J Med (1994) 330:1871-9. doi:10.1056/NEJM199406303302608
192. Zeller CB, Appenzeller S. Cardiovascular disease in systemic lupus erythematosus: the role of traditional and lupus related risk factors. Curr Cardiol $\operatorname{Rev}(2008)$ 4:116-22. doi:10.2174/157340308784245775

193. Manzi S, Meilahn EN, Rairie JE, Conte CG, Medsger TA Jr, JansenMcWilliams L, et al. Age-specific incidence rates of myocardial infarction and angina in women with systemic lupus erythematosus: comparison with the Framingham Study. Am J Epidemiol (1997) 145:408-15. doi:10.1093/ oxfordjournals.aje.a009122

194. Stahl NI, Decker JL. Androgenic status of males with systemic lupus erythematosus. Arthritis Rheum (1978) 21:665-8. doi:10.1002/art.1780210609

195. Jimenez-Balderas FJ, Tapia-Serrano R, Fonseca ME, Arellano J, Beltran A, Yanez $\mathrm{P}$, et al. High frequency of association of rheumatic/autoimmune diseases and untreated male hypogonadism with severe testicular dysfunction. Arthritis Res (2001) 3:362-7. doi:10.1186/ar328

196. Olsen NJ, Kovacs WJ. Case report: testosterone treatment of systemic lupus erythematosus in a patient with Klinefelter's syndrome. Am J Med Sci (1995) 310:158-60. doi:10.1097/00000441-199510000-00006

197. Sasaki N, Yamauchi K, Sato R, Masuda T, Sawai T, Inoue H. Klinefelter's syndrome associated with systemic lupus erythematosus and autoimmune hepatitis. Mod Rheumatol (2006) 16:305-8. doi:10.1007/s10165-006-0511-5

198. Bove R. Autoimmune diseases and reproductive aging. Clin Immunol (2013) 149:251-64. doi:10.1016/j.clim.2013.02.010

199. Jungers P, Nahoul K, Pelissier C, Dougados M, Tron F, Bach JF. Low plasma androgens in women with active or quiescent systemic lupus erythematosus. Arthritis Rheum (1982) 25(4):454-7. doi:10.1002/art.1780250415

200. Lahita RG, Bradlow HL, Ginzler E, Pang S, New M. Low plasma androgens in women with systemic lupus erythematosus. Arthritis Rheum (1987) 30:241-8. doi:10.1002/art.1780300301

201. Treadwell EL, Wiley K, Word B, Melchior W, Tolleson WH, Gopee N, et al. Prolactin and dehydroepiandrosterone levels in women with systemic lupus erythematosus: the role of the extrapituitary prolactin promoter polymorphism at -1149G/T. J Immunol Res (2015) 2015:435658. doi:10.1155/ 2015/435658

202. Lahita RG. Sex hormones as immunomodulators of disease. Ann N Y Acad Sci (1993) 685:278-87. doi:10.1111/j.1749-6632.1993.tb35876.x

203. Cutolo M, Sulli A, Capellino S, Villaggio B, Montagna P, Seriolo B, et al. Sex hormones influence on the immune system: basic and clinical aspects in autoimmunity. Lupus (2004) 13:635-8. doi:10.1191/0961203304lu1094oa

204. Tessnow AH, Olsen NJ, Kovacs WJ. Expression of humoral autoimmunity is related to androgen receptor CAG repeat length in men with systemic lupus erythematosus. JClin Immunol (2011) 31:567-73. doi:10.1007/ s10875-011-9519-5

205. Estes D, Christian CL. The natural history of systemic lupus erythematosus by prospective analysis. Medicine (Baltimore) (1971) 50:85-95. doi:10.1097/00005792-197103000-00001

206. Studenski S, Allen NB, Caldwell DS, Rice JR, Polisson RP. Survival in systemic lupus erythematosus. A multivariate analysis of demographic factors. Arthritis Rheum (1987) 30:1326-32. doi:10.1002/art.1780301202

207. Sthoeger ZM, Geltner D, Rider A, Bentwich Z. Systemic lupus erythematosus in 49 Israeli males: a retrospective study. Clin Exp Rheumatol (1987) 5:233-40.

208. Jonsson H, Nived O, Sturfelt G. Outcome in systemic lupus erythematosus: a prospective study of patients from a defined population. Medicine (Baltimore) (1989) 68:141-50. doi:10.1097/00005792-198905000-00002

209. Reveille JD, Bartolucci A, Alarcon GS. Prognosis in systemic lupus erythematosus. Negative impact of increasing age at onset, black race, and thrombocytopenia, as well as causes of death. Arthritis Rheum (1990) 33:37-48. doi:10.1002/art.1780330105

210. Pistiner M, Wallace DJ, Nessim S, Metzger AL, Klinenberg JR. Lupus erythematosus in the 1980s: a survey of 570 patients. Semin Arthritis Rheum (1991) 21:55-64. doi:10.1016/0049-0172(91)90057-7

211. Wallace DJ, Podell T, Weiner J, Klinenberg JR, Forouzesh S, Dubois EL. Systemic lupus erythematosus - survival patterns. Experience with 609 patients. JAMA (1981) 245:934-8. doi:10.1001/jama.245.9.934

212. Folomeev M, Alekberova Z. Survival pattern of 120 males with systemic lupus erythematosus. J Rheumatol (1990) 17:856-9.

213. Ward MM, Pyun E, Studenski S. Long-term survival in systemic lupus erythematosus. Patient characteristics associated with poorer outcomes. Arthritis Rheum (1995) 38:274-83. doi:10.1002/art.1780380218 
214. Blanco FJ, Gomez-Reino JJ, de la Mata J, Corrales A, Rodriguez-Valverde V, Rosas JC, et al. Survival analysis of 306 European Spanish patients with systemic lupus erythematosus. Lupus (1998) 7:159-63. doi:10.1191/ 096120398678919930

215. Kiss E, Regeczy N, Szegedi G. Systemic lupus erythematosus survival in Hungary. Results from a single centre. Clin Exp Rheumatol (1999) 17:171-7.

216. Tareyeva IE, Janushkevitch TN, Tuganbekova SK. Lupus nephritis in males and females. Proc Eur Dial Transplant Assoc Eur Ren Assoc (1985) 21:712-6.

217. Blum A, Rubinow A, Galun E. Predominance of renal involvement in male patients with systemic lupus erythematosus. Clin Exp Rheumatol (1991) 9: 206-7.

218. Mok CC, Lau CS, Chan TM, Wong RW. Clinical characteristics and outcome of southern Chinese males with systemic lupus erythematosus. Lupus (1999) 8:188-96. doi:10.1191/096120399678847605

219. Stein CM, Olson JM, Gray-McGuire C, Bruner GR, Harley JB, Moser KL. Increased prevalence of renal disease in systemic lupus erythematosus families with affected male relatives. Arthritis Rheum (2002) 46:428-35. doi:10.1002/art.10105

220. Letchumanan P, Thumboo J. Danazol in the treatment of systemic lupus erythematosus: a qualitative systematic review. Semin Arthritis Rheum (2011) 40:298-306. doi:10.1016/j.semarthrit.2010.03.005

221. Agnello V, Pariser K, Gell J, Gelfand J, Turksoy RN. Preliminary observations on danazol therapy of systemic lupus erythematosus: effects on DNA antibodies, thrombocytopenia and complement. J Rheumatol (1983) 10:682-7.

222. Hazelton RA, McCruden AB, Sturrock RD, Stimson WH. Hormonal manipulation of the immune response in systemic lupus erythematosus: a drug trial of an anabolic steroid, 19-nortestosterone. Ann Rheum Dis (1983) 42: 155-7. doi:10.1136/ard.42.2.155

223. Lahita RG, Cheng CY, Monder C, Bardin CW. Experience with 19nortestosterone in the therapy of systemic lupus erythematosus: worsened disease after treatment with 19-nortestosterone in men and lack of improvement in women. J Rheumatol (1992) 19:547-55.

224. Chang DM, Lan JL, Lin HY, Luo SF. Dehydroepiandrosterone treatment of women with mild-to-moderate systemic lupus erythematosus: a multicenter randomized, double-blind, placebo-controlled trial. Arthritis Rheum (2002) 46:2924-7. doi:10.1002/art.10615

225. van Vollenhoven RF. Dehydroepiandrosterone for the treatment of systemic lupus erythematosus. Expert Opin Pharmacother (2002) 3:23-31. doi:10.1517/14656566.3.1.23

226. Petri MA, Mease PJ, Merrill JT, Lahita RG, Iannini MJ, Yocum DE, et al. Effects of prasterone on disease activity and symptoms in women with active systemic lupus erythematosus. Arthritis Rheum (2004) 50:2858-68. doi:10.1002/art.20427

227. Nordmark G, Bengtsson C, Larsson A, Karlsson FA, Sturfelt G, Ronnblom L. Effects of dehydroepiandrosterone supplement on health-related quality of life in glucocorticoid treated female patients with systemic lupus erythematosus. Autoimmunity (2005) 38:531-40. doi:10.1080/08916930500285550

228. Petri MA, Lahita RG, van Vollenhoven RF, Merrill JT, Schiff M, Ginzler EM, et al. Effects of prasterone on corticosteroid requirements of women with systemic lupus erythematosus: a double-blind, randomized, placebocontrolled trial. Arthritis Rheum (2002) 46:1820-9. doi:10.1002/art.10364

229. Marder W, Somers EC, Kaplan MJ, Anderson MR, Lewis EE, McCune WJ. Effects of prasterone (dehydroepiandrosterone) on markers of cardiovascular risk and bone turnover in premenopausal women with systemic lupus erythematosus: a pilot study. Lupus (2010) 19:1229-36. doi:10.1177/ 0961203310371156

230. Hartkamp A, Geenen R, Godaert GL, Bijl M, Bijlsma JW, Derksen RH. Effects of dehydroepiandrosterone on fatigue and well-being in women with quiescent systemic lupus erythematosus: a randomised controlled trial. Ann Rheum Dis (2010) 69:1144-7. doi:10.1136/ard.2009.117036

231. Celhar T, Fairhurst AM. Modelling clinical systemic lupus erythematosus: similarities, differences and success stories. Rheumatology (Oxford) (2017) 56:i88-99. doi:10.1093/rheumatology/kew400

232. Roubinian JR, Talal N, Greenspan JS, Goodman JR, Siiteri PK. Delayed androgen treatment prolongs survival in murine lupus. J Clin Invest (1979) 63:902-11. doi:10.1172/JCI109390

233. Gubbels Bupp MR, Jorgensen TN, Kotzin BL. Identification of candidate genes that influence sex hormone-dependent disease phenotypes in mouse lupus. Genes Immun (2008) 9:47-56. doi:10.1038/sj.gene.6364447
234. Roubinian JR, Talal N, Greenspan JS, Goodman JR, Siiteri PK. Effect of castration and sex hormone treatment on survival, anti-nucleic acid antibodies, and glomerulonephritis in NZB/NZW F1 mice. J Exp Med (1978) 147:1568-83. doi:10.1084/jem.147.6.1568

235. Roubinian JR, Papoian R, Talal N. Androgenic hormones modulate autoantibody responses and improve survival in murine lupus. J Clin Invest (1977) 59:1066-70. doi:10.1172/JCI108729

236. Verheul HA, Deckers GH, Schuurs AH. Effects of nandrolone decanoate in NZB/W mice treated concomitantly with maintenance doses of dexamethasone sodium phosphate. Int J Immunopharmacol (1985) 7:249-54. doi:10.1016/0192-0561(85)90033-5

237. Verheul HA, Deckers GH, Schuurs AH. Effects of nandrolone decanoate or testosterone decanoate on murine lupus: further evidence for a dissociation of autoimmunosuppressive and endocrine effects. Immunopharmacology (1986) 11:93-9. doi:10.1016/0162-3109(86)90029-9

238. Verheul HA, Stimson WH, den Hollander FC, Schuurs AH. The effects of nandrolone, testosterone and their decanoate esters on murine lupus. Clin Exp Immunol (1981) 44:11-7.

239. Verheul HA, Schot LP, Deckers GH, Schuurs AH. Effects of tibolone, lynestrenol, ethylestrenol, and desogestrel on autoimmune disorders in NZB/W mice. Clin Immunol Immunopathol (1986) 38:198-208. doi:10.1016/00901229(86)90138-8

240. Lucas JA, Ahmed SA, Casey ML, MacDonald PC. Prevention of autoantibody formation and prolonged survival in New Zealand black/New Zealand white F1 mice fed dehydroisoandrosterone. J Clin Invest (1985) 75:2091-3. doi:10.1172/JCI111929

241. Steinberg AD, Melez KA, Raveche ES, Reeves JP, Boegel WA, Smathers PA, et al. Approach to the study of the role of sex hormones in autoimmunity. Arthritis Rheum (1979) 22:1170-6. doi:10.1002/art.1780221103

242. Walker SE, Besch-Williford CL, Keisler DH. Accelerated deaths from systemic lupus erythematosus in NZB x NZW F1 mice treated with the testosterone-blocking drug flutamide. J Lab Clin Med (1994) 124:401-7.

243. Jackson SW, Kolhatkar NS, Rawlings DJ. B cells take the front seat: dysregulated B cell signals orchestrate loss of tolerance and autoantibody production. Curr Opin Immunol (2015) 33:70-7. doi:10.1016/j.coi.2015.01.018

244. Papoian R, Pillarisetty R, Talal N. Immunological regulation of spontaneous antibodies to DNA and RNA. II. Sequential switch from IgM to IgG in NZB/NZW F1 mice. Immunology (1977) 32:75-9.

245. Roubinian J, Talal N, Siiteri PK, Sadakian JA. Sex hormone modulation of autoimmunity in NZB/NZW mice. Arthritis Rheum (1979) 22(11):1162-9. doi:10.1002/art.1780221102

246. Shear HL, Roubinian JR, Gil P, Talal N. Clearance of sensitized erythrocytes in NZB/NZW mice. Effects of castration and sex hormone treatment. Eur J Immunol (1981) 11:776-80. doi:10.1002/eji.1830111008

247. Churchill WH Jr, Weintraub RM, Borsos T, Rapp HJ. Mouse complement: the effect of sex hormones and castration on two of the late-acting components. J Exp Med (1967) 125:657-72. doi:10.1084/jem.125.4.657

248. Shreffler DC. The S region of the mouse major histocompatibility complex (H-2): genetic variation and functional role in complement system. Transplant Rev (1976) 32:140-67.

249. Ferreira A, Takahashi M, Nussenzweig V. Purificaiton and characterization of mouse serum protein with specific binding affinity for C4 (Ss protein). J Exp Med (1977) 146:1001-8. doi:10.1084/jem.146.4.1001

250. Der E, Dimo J, Trigunaite A, Jones J, Jorgensen TN. Gr1+ cells suppress T-dependent antibody responses in (NZB x NZW)F1 male mice through inhibition of $\mathrm{T}$ follicular helper cells and germinal center formation. J Immunol (2014) 192:1570-6. doi:10.4049/jimmunol.1302479

251. Touw IP, van de Geijn GJ. Granulocyte colony-stimulating factor and its receptor in normal myeloid cell development, leukemia and related blood cell disorders. Front Biosci (2007) 12:800-15. doi:10.2741/2103

252. Zavala F, Masson A, Hadaya K, Ezine S, Schneider E, Babin O, et al. Granulocyte-colony stimulating factor treatment of lupus autoimmune disease in MRL-lpr/lpr mice. J Immunol (1999) 163:5125-32.

253. Eyles JL, Hickey MJ, Norman MU, Croker BA, Roberts AW, Drake SF, et al. A key role for G-CSF-induced neutrophil production and trafficking during inflammatory arthritis. Blood (2008) 112:5193-201. doi:10.1182/ blood-2008-02-139535

254. Lantow M, Sivakumar R, Zeumer L, Wasserfall C, Zheng YY, Atkinson MA, et al. The granulocyte colony stimulating factor pathway regulates autoantibody 
production in a murine induced model of systemic lupus erythematosus. Arthritis Res Ther (2013) 15:R49. doi:10.1186/ar4208

255. Cook MB, McGlynn KA, Devesa SS, Freedman ND, Anderson WF. Sex disparities in cancer mortality and survival. Cancer Epidemiol Biomarkers Prev (2011) 20:1629-37. doi:10.1158/1055-9965.EPI-11-0246

256. Cook MB. Epidemiology: excess cancer in men - a call for an increased research focus. Nat Rev Clin Oncol (2013) 10:186-8. doi:10.1038/nrclinonc. 2013.37

257. Dorak MT, Karpuzoglu E. Gender differences in cancer susceptibility: an inadequately addressed issue. Front Genet (2012) 3:268. doi:10.3389/fgene. 2012.00268

258. Dev R, Hui D, Del FE, Delgado-Guay MO, Sobti N, Dalal S, et al. Association between hypogonadism, symptom burden, and survival in male patients with advanced cancer. Cancer (2014) 120:1586-93. doi:10.1002/ cncr.28619

259. Ose J, Poole EM, Schock H, Lehtinen M, Arslan AA, Zeleniuch-Jacquotte A, et al. Androgens are differentially associated with ovarian cancer subtypes in the ovarian cancer cohort consortium. Cancer Res (2017) 77:3951-60. doi:10.1158/0008-5472.CAN-16-3322

260. Kaaks R, Berrino F, Key T, Rinaldi S, Dossus L, Biessy C, et al. Serum sex steroids in premenopausal women and breast cancer risk within the European Prospective Investigation into Cancer and Nutrition (EPIC). J Natl Cancer Inst (2005) 97:755-65. doi:10.1093/jnci/dji132

261. Peter HH, Chouroulinkov I, Guillon JC, Ventura A, Lenormand M. The influence of castration and oestradiol treatment on tumor transplan- tation immunity in mice. Z Krebsforsch (1970) 74:207-18. doi:10.1007/ BF00525887

262. Lhoste EF, Roebuck BD, Brinck-Johnsen T, Longnecker DS. Effect of castration and hormone replacement on azaserine-induced pancreatic carcinogenesis in male and female Fischer rats. Carcinogenesis (1987) 8:699-703. doi:10.1093/carcin/8.5.699

263. Deguchi J, Miyamoto M, Okada S. Sex hormone-dependent renal cell carcinogenesis induced by ferric nitrilotriacetate in Wistar rats. Jpn J Cancer Res (1995) 86:1068-71. doi:10.1111/j.1349-7006.1995.tb03022.x

264. Zhang LJ, Xiong Y, Nilubol N, He M, Bommareddi S, Zhu X, et al. Testosterone regulates thyroid cancer progression by modifying tumor suppressorgenes and tumor immunity. Carcinogenesis (2015) 36:420-8. doi:10.1093/ carcin/bgv001

Conflict of Interest Statement: The authors declare that the research was conducted in the absence of any commercial or financial relationships that could be construed as a potential conflict of interest.

Copyright $\odot 2018$ Gubbels Bupp and Jorgensen. This is an open-access article distributed under the terms of the Creative Commons Attribution License (CC BY). The use, distribution or reproduction in other forums is permitted, provided the original author(s) and the copyright owner are credited and that the original publication in this journal is cited, in accordance with accepted academic practice. No use, distribution or reproduction is permitted which does not comply with these terms. 